IZA DP No. 5346

Urban Infrastructure and Economic Development: Experimental Evidence from Street Pavement

Marco Gonzalez-Navarro

Climent Quintana-Domeque

November 2010 


\title{
Urban Infrastructure and Economic Development: Experimental Evidence from Street Pavement
}

\author{
Marco Gonzalez-Navarro \\ University of California, Berkeley \\ Climent Quintana-Domeque \\ Universitat d'Alacant \\ and IZA
}

\author{
Discussion Paper No. 5346 \\ November 2010
}

\author{
IZA \\ P.O. Box 7240 \\ 53072 Bonn \\ Germany \\ Phone: +49-228-3894-0 \\ Fax: +49-228-3894-180 \\ E-mail: iza@iza.org
}

Any opinions expressed here are those of the author(s) and not those of IZA. Research published in this series may include views on policy, but the institute itself takes no institutional policy positions.

The Institute for the Study of Labor (IZA) in Bonn is a local and virtual international research center and a place of communication between science, politics and business. IZA is an independent nonprofit organization supported by Deutsche Post Foundation. The center is associated with the University of Bonn and offers a stimulating research environment through its international network, workshops and conferences, data service, project support, research visits and doctoral program. IZA engages in (i) original and internationally competitive research in all fields of labor economics, (ii) development of policy concepts, and (iii) dissemination of research results and concepts to the interested public.

IZA Discussion Papers often represent preliminary work and are circulated to encourage discussion. Citation of such a paper should account for its provisional character. A revised version may be available directly from the author. 


\section{ABSTRACT}

\section{Urban Infrastructure and Economic Development: Experimental Evidence from Street Pavement}

We design an infrastructure experiment in Mexico to evaluate the impact of street pavement on housing values and household outcomes. We find that the provision of street pavement raises housing values by $16 \%$ and land values by $54 \%$, according to professional appraisals. Using homeowner valuations, we estimate the impact of pavement on housing values to be $25 \%$. At the household level, street paving increased the use of collateral-based credit and average loan size. Additionally, among households on paved streets vehicle ownership went up by $40 \%$, while the number of durable goods augmented by $12 \%$ as a result of pavement. We provide compelling evidence that the mechanism explaining the durable goods increase is the credit channel: the raise in durable goods as well as in credit use was only present among households with access to financial services at baseline. This suggests that increments in the value of collateral are not sufficient to expand credit use in this context. Access to the financial sector is necessary for street pavement to be reflected in higher consumption of durable goods. Finally, we estimate the private gains to land plots on paved streets to be $109 \%$ of construction costs, which can have important implications for urban infrastructure financing.

JEL Classification: C92, C93, H41, O12, O15

Keywords: randomized controlled trial, street pavement, home values, durable goods, credit

Corresponding author:

Climent Quintana-Domeque

Departament de Fonaments de l'Anàlisi Econòmica

Universitat d'Alacant

Campus de Sant Vicent

Alacant 03690

Spain

E-mail: climent@ua.es

\footnotetext{
"We would like to thank Anne Case, Angus Deaton, Alan Krueger, David Lee, Adriana Lleras-Muney, Christina Paxson, and Cecilia Rouse for their support and advice in this research project. The collaboration of the Acayucan 2005-2007 and 2008-2010 Municipal administrations is gratefully acknowledged. We also recognize the effort of José Luis Palma, Luz Uribe and Monica González at INSAD who were in charge of the survey, and José Luis Reyes who provided the house value assessments. We also thank Pierre-André Chiappori, Lucia Corno, Frederico Finan, Paul Gertler, Jeremy Magruder, Edward Miguel, and seminar participants at Berkeley, CEMFI, DIW-Berlin, Princeton, RAND, US Treasury, ASSET Alicante, APPAM, BREAD-MIT, EEA-Glasgow, INSIDE-IAE, LILP-Quito, NEUDC-MIT, Pacific Development Conference, and World Bank Conference on Infrastructure and Development for helpful comments and suggestions. The data collected for this study underwent the approval process of the Institutional Review Panel at Princeton University (Research Protocol 3104). Financial aid and support from Princeton University, Princeton Woodrow Wilson Scholars, Princeton Industrial Relations Section, Princeton Research Program in Development Studies, Robert Wood Johnson Scholars in Health Policy Research Program, Berkeley Economics, Universitat d'Alacant, the Lincoln Institute of Land Policy and the Spanish Ministry of Science and Innovation (ECO 2008-05721/ECON) is gratefully acknowledged. Any errors contained in the paper are our own.
} 


\section{Introduction}

Today's developing countries are urbanizing at a much more rapid pace than that of their predecessors (Henderson, 2002). The combination of this urban population explosion with limited public funds accounts for a worldwide deficiency in urban infrastructure. Today, large portions of the population in metropolitan areas throughout the developing world do not benefit from basic urban equipment such as piped water, electricity, sewerage lines, and asphalted roads (UN-Habitat, 2003). Because those neighborhoods with the lowest levels of infrastructure are home to a city's most impoverished residents it is crucial to better understand the effects of urban infrastructure on economic development (Napier, 2009).

The importance of this issue has become increasingly evident over the past decade with the advent and proliferation of large-scale direct cash-transfer programs such as Progresa / Oportunidades. The extensive evaluation of cash-transfer programs (Skoufias, 2001; Gertler 2004) contrasts starkly with the lack of research into the merits of infrastructure for urban dwellers (World Bank, 1994). We address this gap in the literature by means of a randomized experiment designed to gauge the impact of street pavement in the city of Acayucan, Mexico. ${ }^{1}$

In 2006, in cooperation with the municipal government of Acayucan, we randomly selected from a pre-approved set of street-pavement projects (each defined as a contiguou sets of unpaved city blocks connecting with the city's pavement grid) a subset to be treated with pavement. The streets in question lacked pavement but were fully occupied by private residences.

Our work is the first to address, by the use of random assignment, the problem of selection bias inherent in infrastructure placement. This technique resolves the main endogeneity problem encountered by any study focusing on the impact of infrastructure: a simple comparison of places with and without infrastructure in observational data is misleading, since infrastructure is normally allocated to places that provide the highest returns (Duflo and

\footnotetext{
${ }^{1}$ We use the American term «street pavement» to refer to asphalt/concrete laid down for vehicular traffic. The British English equivalent is «road surface.» Acayucan is one of Mexico's 56 metropolitan areas, encompassing three municipalities with a combined population of 105,500 (INEGI, 2007).
} 
Pande, 2007; Van de Walle, 2002).

We conducted a pair of household surveys: a baseline one, at the start of our study, in 2006, and a follow-up one once the streets had been paved, in 2009; in both instances we obtained professional appraisals of property values as well. Our experimental estimates show that street pavement generated substantial increases in the value of properties on paved streets: according to professional appraisals, residential property values increased by $16 \%$, with a corresponding increase in land values of 54\%. According to homeowners' estimates, street pavement increased housing values by $25 \%$. We corroborate the validity of these measures with two other pieces of market-value information: rents increased by $31 \%$ in paved streets; and for the houses that were purchased between the baseline and follow-up surveys $(N=29)$ the price paid was $85 \%$ higher on paved streets, although the coefficient is insignificant $(p=0.49)$ on account of the limited number of observations. All of our housing-value measures point towards substantial increases due to pavement provision.

Since the provision of pavement did not affect either property-tax rates or property valuations in Acayucan, our experimental valuation of street pavement is the first to measure the willingness of householders to pay more for properties on paved streets. In this respect our study differs from that of Cellini, Ferreira and Rothstein (2010), who have shown that, when local public goods are financed with property taxes (as is the case throughout most of the US), the marginal effect of public-good provision on property values is, in the optimum, zero.

Turning to household-level outcomes, we show that pavement had important positive effects on credit and durable-goods consumption. Collateral-based credit use from financial institutions more than doubled, and loan size went from an average of 150 pesos to 1,651 pesos per adult. ${ }^{2}$ Other forms of credit, including credit from family and friends or the government, did not respond to pavement provision. In terms of durable goods - an important indicator of household well being - vehicle ownership among households benefiting from the provision

\footnotetext{
${ }^{2}$ The 2009 PPP exchange rate was 8.5 pesos to the US dollar, and the nominal February 2009 exchange rate was 14.6 pesos to the US dollar.
} 
increased by more than $40 \%$, while the acquisition of household durable goods increased by $12 \%$.

Because we conducted our follow-up survey over a short period after the paving had occurred, we find no significant evidence of neighborhood recomposition. Furthermore, those who moved did not differ in their observable characteristics, such as per capita expenditure, durable goods, or vehicle ownership, according to whether the streets to and from which they moved were paved or unpaved.

How did households manage to transform pavement into credit and eventually into durable-goods consumption? We offer a simple but compelling answer: They could increase their use of credit and their consumption of durable goods provided that they had access to banking services. Defining such a household as one in which in 2006 (before the intervention) at least one household member had a bank account, we find that increases in both credit use and durable-goods acquisition occurred exclusively among these households. This finding leads us to conclude that access to banking services is crucial to the positive relationship between urban infrastructure and durable-goods consumption. This conclusion is consistent with a large theoretical body of literature (Aghion and Bolton, 1997; Banerjee and Newman, 1993; Banerjee, 2004) and also with empirical evidence related to the expansion of branch banks into rural India in the 1970s and 1980s (Burgess and Pande, 2005; Burgess, Pande, and Wong, 2005).

Given that street pavement generated considerable benefits for property owners along paved streets, we use the approach in Jacoby (2000) in order to compare the benefits of street pavement (the sum of increases in land values across plots) with its costs and conclude that the benefits amounted to $109 \%$ of the costs. This suggests that in the absence of credit constraints, property taxes triggered by public goods that increase land value could be used as a funding device for this type of urban infrastructure.

In sum, we show that urban infrastructure has a significant positive impact on the value of residential properties, which is perhaps the most important indicator of household wealth; 
that street pavement in particular has a significant positive impact as measured by the ratio of private land-value increases to the cost of pavement; and that access to the financial sector is crucial if households are to benefit from urban infrastructure in terms of credit use and durable-goods consumption.

Our work is related to the rapidly expanding literature on the effects of infrastructure. Donaldson (2010) provides evidence that railroad infrastructure increased trade between Indian districts, not only increasing average income but also reducing its volatility. Dinkelman (2008) shows that rural electrification in South Africa has led to a reduction in the time women spend collecting firewood, allowing them to allocate more time to labor-market activities. Duflo and Pande (2007) find that the effects of irrigation dams in India depend on the population's location relative to the dam: downstream, agricultural production rises and rural poverty falls; upstream, the situation is reversed.

The structure of paper is as follows. Section 2 describes the experimental design. Section 3 presents the results. Section 4 provides an economic explanation for our experimental estimates. Section 5 compares the sum of gains in land value on paved streets with construction costs. Finally, Section 6 concludes.

\section{Experimental Design}

\subsection{Institutional Context}

Acayucan is an urban area with a development pattern typical of Mexico and other Latin American countries. That the benefits of municipal services including electricity, sewerage, tap water, street pavement, and public transportation diminish with distance from the city center is primarily due to the fact that public funding of such benefits cannot keep pace with the city's population growth. Upon arriving at the city's outskirts, many of the poorer migrants have no choice but to purchase plots and build houses on tracts of land there, devoid of any urban infrastructure. With the passage of time, demand for basic services 
increases, as does the political pressure to provide them. The usual order is electricity first, followed by water and sewerage lines, and finally street pavement. While unpaved streets are found throughout Acayucan, the highest concentrations are found near the city's limits.

Municipal governments in Mexico are responsible for most of the elements of their urban infrastructure. Each three-year administration has ample leeway as to budgetary allocations. The municipal budget consists mainly of transfers from general funds obtained from the federal value-added tax, the federal income tax, and oil revenues. Less than $10 \%$ of the municipal budget derives from local taxes (consisting of the property tax and business-permit fees). Property-tax receipts, especially in small cities, play a less significant role in Mexico than they do in the US. Cadastral property valuations are very low and rarely updated. Furthermore, in Mexico non-payment of the property tax is not subject to prosecution on the part of the municipal government concerned.

\subsection{The Experiment}

The 2005-2007 Acayucan administration launched a street-paving program targeting those neighborhoods deprived of municipal services. Ideally, all unpaved streets would have benefited, but because of budget constraints the program had to be selective. Recognizing that such selectivity could generate significant findings in regard to the costs and benefits of public-infrastructure investment, we proposed to conduct a randomized evaluation of this paving program.

The administration decided to limit the program to those neighborhoods with relatively high population densities. The administration was responsible for selecting and defining the projects, which consisted of sets of contiguous city blocks that connected with the existing city pavement grid. The mayor and the public-works personnel provided us with a set of 56 such projects, located throughout the city. To qualify, a street had to be unpaved and heavily populated. Given that the administration could afford to pay for only 28 of the 56 projects, the mayor and the city council reasoned that it would be in everybody's interest 
not only for a third party to evaluate the paving program but also for the same third party to select, at random, the 28 streets to be paved. Thus in 2006 we used randomization to make this selection.

It is important to bear in mind that every municipal administration in Acayucan allocates a portion of its budget to street paving. This means that any unpaved street has a positive probability of being paved, although it may mean waiting many years - 15 was the median in our sample. Treatment therefore did not modify the expectations of the control group as to the likelihood of being selected (in the near future). The novelty of our study relies on the randomization: within the subset of street projects that had the highest payoff to municipal authorities, we were allowed to randomize treatment. Figure 1 shows the location of those streets assigned to the treatment group $(Z=1)$ and those assigned to the control group $(Z=0)$. The projects range from 160 to 1,000 meters in length. Note that in Figure 2, a picture of one of the streets selected to be paved in 2006, the plots along the street are fully occupied by houses. For residential investment to take place prior to the provision of public services is rare in developed countries, but extremely common in developing ones.

Several sources of uncertainty that the city government would face throughout the course of the paving project were: volatile funding, cost fluctuations, and foul weather, chiefly. By March 2009, 17 of the streets in the treatment group had been completely paved, two projects were under way, and nine had yet to begin. The municipal government attributed the delays to foul weather and various technical difficulties. On the other hand, the administration did fulfill the requirement of not paving those streets assigned to the control group. The street shown in Figure 3 is the same as that in Figure 2, but after it had been paved. The provision of pavement in this context enhances the residents' sense of inclusion in the city's identity, and is also greatly appreciated not only for its aesthetic value but also its practical importance.

The identity of the streets to be paved was not immediately revealed to the population because budgeting is performed annually, whereas the study would take place over the three 
years of the administration. In other words, the selection was not legally binding in any way that could be announced to the population, but rather served as an internal guideline in the annual budgeting process. Participation in the program was thus reveled to neighbors with the arrival of measurement teams and eventually construction crews and machinery. This helps the research by eliminating anticipation effects in the housing values.

\subsection{Data Sources}

The data for this study are pre- and post-intervention rounds of a dedicated household survey (the Acayucan Standards of Living Survey, ASLS) and professional appraisals of residentialproperty values. ${ }^{3}$ The baseline survey was fielded in February-March 2006, and the follow-up survey was fielded in February-March 2009. Professional appraisals were performed immediately after the survey work.

The target population of the survey consisted of all occupied residential structures on the streets that were selected for the experiment. ${ }^{4}$ The baseline survey was administered to 1,231 households living in 1,193 dwellings, with a response-rate of $94 \% .^{5}$ In $2009,1,083$ households were interviewed. In 900 cases we found the same household that we had interviewed in 2006, and in 156 cases we found that a new household was in residence. In order to assess neighborhood recomposition occurring on account of newcomers moving into new constructions, all families living in residences built between baseline and follow-up were also interviewed $(\mathrm{N}=27)$. Table A1 details survey response rates. ${ }^{6}$

\footnotetext{
${ }^{3}$ A full description of the ASLS can be found in Gonzalez-Navarro and Quintana-Domeque (2010). We also obtained information on business units from a brief business census conducted in 2006 and 2009 .

${ }^{4}$ We created a sampling frame from all inhabited residential dwellings in January 2006. As Deaton (1997) recognized, the use of outdated or otherwise inaccurate sampling frames is an important source of error in survey estimates. The sampling procedure was clustered sampling: From the list of dwellings in each cluster we chose at random a specified fraction to be interviewed.

${ }^{5}$ Some dwellings contained more than one household (defined as a group of one or more persons living in the same house and sharing food expenditures). The procedure in the case of such multiple households was to interview all of them. It is worth noting that neither quota sampling nor substitution of non-responding households or individuals (whether refusals or non-contacts) was permitted at any stage.

${ }^{6}$ We determined that there was a risk that not all of the streets selected for treatment would in fact be treated by the time of the follow-up survey. Indeed, as we have seen in the previous subsection, there were 11 such cases. In order to maximize the power of our tests, sampling was done with a higher intensity in the
} 
The household questionnaire collects detailed information for each individual in the household (age, sex, educational attainment, labor supply, etc.) and characteristics at the household level (per capita expenditure, durable goods, vehicle ownership, home investments, etc.). In over $95 \%$ of the cases household and individual questions were answered by a reference person who was thus targeted because he or she was either the household head or the spouse/partner of the head. It is important to emphasize that the municipality did not announce to the population the existence of this study. Moreover, participants in the study (household respondents and the professional appraiser) were not aware of the ultimate objective of the survey. We also trained field workers not to mention the phrase "street pavement" to respondents. Thus, any behavioral bias among the treatment group (Hawthorne effects) and among the control group (John Henry effects) was minimized.

In Table 1 we present descriptive statistics for the city of Acayucan in column 1, and for the experimental streets in column $2 .^{7}$ According to the 2005 short census (Conteo), the municipality has a population of 79,459, with the city accounting for about 50,000. The average altitude is 100 meters above sea level, and the climate is tropical. Of those aged 15 and older, $9 \%$ are illiterate. School enrollment is $94 \%$ among adolescents aged 12-14. Water is piped to the lots or homes of $84 \%$ of households, and electricity to $98 \%$. As for major appliances, $81 \%$ of homes have a refrigerator, $55 \%$ have a washing machine, and $14 \%$ have computers.

The descriptive statistics from the 2006 ASLS survey in column 2 are close to those of the 2005 census, with the exception of the proportion of households having access to piped water in their lot and the number of rooms in the house, which are lower in our survey. These data underscore the fact that, while the indicators for census tracts with streets included in the experiment are inferior to those for city-center census tracts, the indicators of many areas intent-to-treat group (List, Sadoff, and Wagner, 2009). We sampled at a rate of $70 \%$ in the intent-to-treat (ITT) group and at a rate of $50 \%$ in the control group.

7 The information in Table 1 refers exclusively to the city of Acayucan; it does not include non-urban localities in the municipality or Oluta and Soconusco, the other two municipalities that are part of the metropolitan area. 
that were not part of the experiment were even worse. The poorest families were living in areas dominated by vacant lots, and the municipal government could not as yet afford to provide urban infrastructure to such underpopulated neighborhoods.

\subsubsection{Measuring House Prices}

The main challenge in assessing changes in property value occurring in small geographical areas over a short time span is the paucity of transactions. Moreover, in the case of a developing country, transactions registered in the state property registry are unreliable indicators of transaction prices, since the term often used is gift, donation, or inheritance, in order to reduce taxes. ${ }^{8}$ Even for properties registered as having been sold, in many cases there is a substantial lag between the date of the transaction and the date of registry. It seems that in developing countries it is often the case that an individual buys and moves into a house and only later pays the transaction taxes and registers as its owner. In the US, in contrast, property registries are the main data source for home-price indices (Case and Shiller, 1987). Again, however, these registries are useful for assessing changes in property values only over large geographical areas, such as entire cities.

To compensate for the small number of transactions to be expected in our setting, we obtained two independent measures of property value: professional appraisals and homeowner valuations. The fact that professional appraisals are used by banks to determine property values, and hence the size of loans, indicates that they are a reliable source of market valuation. In our case, we used the services of a professional appraiser who was also a real-estate agent in the city. We used the services of the same agent in 2006 and 2009 in order to minimize heterogeneity of assessment practices, which require subjective decision-making. Each appraisal consisted of a visit by the expert to the property and a careful evaluation of the

\footnotetext{
8 Our conversations with local public notaries and municipal authorities revealed that since valuation for property-tax purposes is set as the maximum between the last declared transaction price and the very conservative property-tax assessed value, individuals do not usually report the actual amount paid for the property.
} 
approximate sale price of the property. ${ }^{9}$ We obtained professional appraisals of residential property (and land) value for half of the successfully interviewed households. ${ }^{10}$

The second main source of property valuation we obtained were homeowners' self-reports. Self-reported home values have long been used for research on housing economics (in developed countries see Kish and Lansing, 1954; Kain and Quigley, 1972; Goodman and Ittner, 1992; Kiel and Zabel, 1999; Bucks and Pence, 2006; in developing countries see Jimenez, 1982). This literature concludes that the evolution of self-reported housing prices generally mimics that of actual prices. In the ASLS, we asked: "Approximately how much money do you think this house could sell for nowadays?"

For the 2006 ASLS sample, Gonzalez-Navarro and Quintana-Domeque (2009) have shown that owners overestimate the value of their homes relative to the appraiser but that the bias is explained by long tenure: short-tenured homeowners provide value assessments that are on average the same as professional appraisals. ${ }^{11}$ This suggests the professional appraiser's valuation is a better indicator of market value.

We can validate the professional appraisals and self valuations with the limited number of market transactions data in our sample. We ask recent buyers - those arriving between baseline and follow-up - how much they paid for the property. We ask recent renters how much they pay per month in rent. This last measure has the advantage that we can check for balance of the rent being paid on the same properties at baseline.

\footnotetext{
${ }^{9}$ Appraisers define market value as "The most probable price, as of a specified date, in cash, for which the specified property rights should sell after reasonable exposure in a competitive market under all conditions requisite to fair sale, with the buyer and seller each acting prudently, knowledgeably, and for self-interest, and assuming that neither is under undue duress."

${ }^{10}$ On account of budgetary constraints we did not obtain appraisals from all interviewed homes. The appraiser did not enter the properties because previous research has shown that doing so does not increase accuracy (Kish and Lansing, 1954).

${ }^{11}$ In the 2009 sample the mean difference between $\log$ appraised value and $\log$ homeowner valuation is -0.39 for the whole sample, and only -0.04 for short-tenure homeowners.
} 


\subsubsection{Credit and Consumption Measures}

The ASLS asks for credit use at the individual level for all adults. Credit use and loan size are available for collateral-based credit (composed of mortgages, home-equity lines, and collateralized bank loans); non-collateralized credit (composed of appliance- and furniturestore credit, bank-card credit, vehicle loans, and casas de crédito popular loans); credit from informal lenders, credit from family and friends, and credit from government entities. In addition, the ASLS asks whether anyone in the household has a bank account (checking, direct deposit, or savings). Consumption of non-durable goods is measured by monthly household per capita expenditure. We have two measures of per capita expenditure: one indirect measure, based on expenditures on eight major items (food, phone, gas, electricity, education, rent or mortgage, clothes, and entertainment), and one direct measure, based on total reported expenditures. ${ }^{12}$ Consumption of durable goods is measured according to two indices: one of vehicle ownership (the sum of automobile, truck, and motorcycle) and one of household durables (the sum of refrigerator, washing machine, microwave oven, air conditioning, video player, and computer).

\subsubsection{Other Measures}

The ASLS also contains information on labor supply (households respondents were asked, for instance, to specify the number of hours each working adult worked per day/per week and the income earned there from), transportation costs (the time it takes to go to the city center using the habitual means of transport and the price of a taxi from the home to the city center), health (symptoms of poor health among household members over the previous year), and children's schooling (school enrollment and absenteeism).

\footnotetext{
12 Interviewers were asked to perform a consistency check permitting them to verify that total reported expenditures were at least as large as the sum of itemized expenditures.
} 


\subsection{Identification}

In line with the established impact-evaluation literature (e.g., Kling, Liebman, and Katz, 2007), we estimate intent-to-treat (ITT) and treatment-on-treated (TOT) effects. Let $Y_{2009}$ be the outcome of interest in 2009 and let $Z$ be an indicator for pavement-group assignment. We estimate

$$
Y_{2009}=\alpha_{0}+\alpha_{1} Z+\alpha_{2} Y_{2006}+\epsilon_{1}
$$

where $Y_{2006}$ is included to improve precision. The ITT parameter is $\alpha_{1}$ in equation (1).

We estimate the TOT effect using pavement group assignment as an instrumental variable for the street being paved, so $Z$ is the excluded instrument for an indicator $D$ of being paved in the two stage least squares (2SLS) estimation:

$$
Y_{2009}=\beta_{0}+\beta_{1} D+\beta_{2} Y_{2006}+\epsilon_{2}
$$

The TOT parameter $\beta_{1}$ is equal to the ITT parameter divided by the regression-adjusted compliance rate - the fraction of observations that were finally paved among those originally selected to be paved. We interpret these 2SLS estimates as treatment-on-treated estimates because paving was not applied to streets in the control group. In other words, there is only one-sided non-compliance (Bloom, 1984; Angrist, Imbens, and Rubin, 1996). The TOT is identified under the assumption that there was no average effect of pavement-group assignment on those households living on streets that were not finally paved (we provide evidence below that this assumption holds). We cluster standard errors at the street-pavement-project level and use survey weights. ${ }^{13}$

\footnotetext{
${ }^{13}$ Survey weights (or expansion factors) represent the inverse of the probability that a dwelling or household is included in the sample. In constructing them we took into account the proportion of households whom we attempted to interview in each cluster and cluster-specific non-response.
} 


\section{Results}

Our dataset contains three types of households: those interviewed in 2006 and 2009; those interviewed in 2006 but not subsequently because they moved out of; and immigrant households for which we only have information from the 2009 round. Table A1 shows that by the time of the follow-up survey in 2009, 271 baseline households (in our original sample) had moved out, while 183 immigrant households (not in our original sample) moved into, the experiment's streets. We need to determine whether the attrition in our panel caused by the baseline households that moved out is random. If it is, experimental estimates based on stayers will be consistent but imprecise; if it is not, the estimates will be inconsistent.

The top panels in Table A2 and Table A3 show that neither out-migration nor immigration was affected by treatment status. ${ }^{14}$ Moreover, the lower panel in Table A2 shows that when it comes to per capita expenditure, durable goods, and vehicle ownership there was no difference between out-migrants from control streets and those from paved streets. Similarly, the lower panel in Table A3 shows that there was no difference between immigrants into treatment streets and those into non-treatment streets. ${ }^{15}$

Given the short-term nature of the experimental evaluation, we cannot prove that migration to and from experimental streets was (mean) independent of treatment status. We therefore do not rule out the possibility that over the long term the paving of a neighborhood's streets would cause a recomposition of that neighborhood.

Having shown that our estimates are not inconsistent on account of out-migrant-basedattrition and that differential immigration flows to paved and unpaved streets had no masked effects, we turn our attention to stayers.

\footnotetext{
14 The sampling frame in 2006 was occupied dwellings. In 2009, some of these dwellings may have been temporarily unoccupied, hence the higher out-migration rate.

15 Differences along other dimensions were also checked, with similar results.
} 


\subsection{Baseline Balance}

Table 2 presents average baseline characteristics by treatment status for our main outcome variables. ${ }^{16}$ The table shows that randomization was successful in balancing pre-treatment characteristics across both the intent-to-treat and the control groups. ${ }^{17}$

We assessed a total of 50 variables and found evidence of balanced characteristics across the groups. The only variable that was significantly different was labor income in the ITT group, which was $17 \%$ higher than in the control group $(\mathrm{ITT}=0)$ at the $10 \%$ significance level.

Table 2 also provides insightful descriptive statistics. Around $16 \%$ of households had a bank account in 2006. Average expenditure per capita at baseline was 828 Mexican pesos, slightly higher than the poverty line, of $\$ 2$ a day (Banerjee and Duflo, 2007). ${ }^{18}$ At baseline, the index of household vehicle ownership (sum of car, truck, and motorcycle) is $21 \%$, and the average household has two out of the six items in the durable-goods category.

\subsection{Experimental Estimates}

\subsubsection{Effects on Home and Land Values}

We begin by presenting, in the three columns of Table 3, our main experimental estimates for the effect of street pavement on home and land values. ITT and TOT estimated effects are presented in the first two columns and the mean of the corresponding variable for the control group in 2009 in the third. Using the professional-appraisal measures, we find that pavement increased home values by $16 \%$ and land values by $54 \%$. Using homeowners' valuations, we estimate that street pavement increased property values by $25 \%$. The fact that two

\footnotetext{
${ }^{16}$ Additional outcomes can be found in Table A4 in the Appendix.

17 An alternative test of equality of means is a two sample $t$-test with unequal variances between groups using Welch's (1947) approximation. This alternative provides a solution to the Fisher-Behrens problem of testing the significance of the difference between the means of two normal populations with different variances. The standard errors using this alternative test were very similar to the regression based standard errors, so we follow usual practice. See Deaton (2009) for further discussion.

18 This was the poverty line in 1985 ; by 2005 it had risen to $\$ 2.92$.
} 
independent measures of property value move in the same direction suggests that paving accounts for substantial increases in value. ${ }^{19}$

To our knowledge, these are the first experimental estimates of the impact of this type of basic urban infrastructure on property values. With respect to the literature on hedonic estimates of the value of amenities (see Rosen, 1974; the identification criticisms in Brown and Rosen, 1982; and Kanemoto, 1988), our estimates have an advantage in that we randomized the amenity at stake. Furthermore, given that homeowners who obtained pavement did not see an increase in their property taxes, our estimates can be interpreted as the marginal willingness to pay for this amenity. This contrasts with a situation in which identical neighbors vote on the amount of public goods to be financed by property taxes: in equilibrium, a marginal increase in the public good has no effect on average property values because the public good's valuation is exactly offset by the tax increase (Cellini, Ferreira and Rothstein; $2010) \cdot .^{20}$

Table 3 also shows that rents on treated streets were $31 \%$ higher than rents on control streets, controlling for rent paid by the previous renter for the same property, and that the prices paid for recently purchased houses on ITT and paved (TOT) streets are $44 \%$ and $85 \%$ higher than in the control group, although it must be conceded that, because the sample was small, this estimate is very imprecise. However, both supplemental indicators corroborate the estimates obtained from appraisals and homeowner valuations, and even suggest that the most conservative impact estimates are those given by the appraiser.

Identification of the TOT effect is based on the assumption that there was no average effect of pavement-group assignment on those households living in places that were not finally paved. One potential concern is that non-compliers, i.e., people living along the ITT streets that were not finally paved, knew that their street had been selected and modified their estimates of their property's value even before the streets were paved. The appraiser could

\footnotetext{
19 The difference in the magnitudes of the estimated impacts is not statistically significant. The standard error of the estimated impact using homeowners valuation is three times higher than the one corresponding to the estimated impact using the professional-appraisal valuation.

${ }^{20}$ See also Brueckner (1982) and Haughwout (2002).
} 
have updated his estimations of such properties as well. In any case, non-compliers would be affected by owning a house on a street selected for paving in the near future, and "being in a selected project" could not be used as an instrument for "being paved." Table A5 shows that there was no increase in home values for those homes in the intent-to-treat group that were not finally paved, suggesting that the expectations of non-compliers regarding home prices did not change. ${ }^{21}$

Finally, we note that our estimates provide lower bounds of the effect on housing for two different reasons. The first is the existence of indirect treatment effects. As long as distance to the nearest paved street is a determinant of housing value, households in the control group may have benefitted from the pavement provided to the treated group. This would be the case if a pavement project in the treatment group reduced the distance to the nearest paved street for some homes in the control group. In fact, we observe an average reduction of 0.68 street blocks among the control group between baseline and follow-up, and increases in home value among the control group that are correlated with the reduction in distance to the nearest paved street (Figure 4). This suggests that there may be a slight downward bias to our estimates of the impact on property values.

General-equilibrium effects, too, may help to account for a downward bias. The provision of street pavement can be thought of as having increased the citywide supply of houses on paved streets and decreased the citywide supply of houses on unpaved ones. Although the latter commands higher prices than the former, the general-equilibrium effect is to reduce the price of houses on paved streets and increase the price of houses on unpaved ones. To measure general-equilibrium effects (something our experiment was not designed to do), one should randomize intensity of street pavement across otherwise similar cities. ${ }^{22}$

\footnotetext{
21 This is also consistent with the local government's not announcing which streets were in the ITT group.

${ }^{22}$ In an attempt to assess the importance of these general-equilibrium and indirect-treatment effects, we estimate the following model for the group of homes in the control group (ITT=0):

$$
Y_{2009}=\gamma_{0}+\gamma_{1} \Delta d+\gamma_{2} C+\gamma_{3} Y_{2006}+\epsilon_{3}
$$

where $Y_{2009}$ is appraisal's home valuation in $2009, \Delta d$ is the change in distance to the nearest paved street between 2006 and 2009 and $C$ is an indicator of whether the home was located on a corner of a paved street,
} 


\subsubsection{Effects on Credit and Consumption}

We now turn to the effects of street-pavement provision on credit use and consumption. Table 4 shows that pavement increased the percentage of individuals who use collateralbased credit from 2\% among the control group to 5\% among the treated. The increased use of collateral-based credit is also reflected in the average loan size, on average 150 pesos among the control group and 1,651 pesos among the treated: a more than tenfold increase. While this is an important finding, we do not have the information needed to determine whether the increase in collateral-based credit use is due to an increase in either the demand for credit (wealth effects) or the supply of credit (more approvals and higher authorized loans). ${ }^{23}$

When we look at all other types of credit, such as non-collateral based, credit from family and friends, credit from government entities, and credit from informal sources, we do not observe any changes either in the number of individuals using credit or in the extent of the credit. $^{24}$

Consumption effects are reported in Table 5. Street-pavement provision had a strong positive effect on the number of durable goods owned by the household: out of six durable goods, control households had an average of 2.4 goods, while the mean for households on paved streets was 2.7 goods (12\% higher). There was also a significant effect on the rate of ownership of a motorized vehicle (motorcycle, car, or truck). Whereas the household-vehicle index is 0.25 (out of three) in the control group, in the treated it is 0.35 , corresponding to a

the idea being that a home that is on a corner where a paved street meets an unpaved one can be thought of as having access to pavement. The indirect-treatment effect is captured with $\gamma_{1}$ and the general-equilibrium effect with $\gamma_{2}$. Our estimates for $\gamma_{1}$ and $\gamma_{2}$ are $-0.034(\mathrm{se}=0.026)$ and -0.009 (se=0.032), respectively. On the one hand, a decrease of one street block in the distance between a given house and the pavement grid was correlated with a $3 \%$ higher housing value. On the other hand, the provision of street pavement was correlated with a reduction of $1 \%$ in the price of homes that already benefited from pavement (on one side of the house). In both cases one should bear in mind that it is difficult to estimate these effects with any precision.

${ }^{23}$ See Field and Torero (2004).

${ }^{24}$ In terms of access to the banking sector in 2009 - determined according to whether someone in the household had a bank account in 2009 - we find a seven-percentage-point increase in bank accounts over a control-group rate of $16 \%$. The effect is close to being statistically significant. 
$43 \%$ increase.

In Acayucan, as in many other cities in developing countries, households improve and expand their houses over time. In terms of recent home investments, we find a doubling in the average number of home improvements a household engaged in over the previous six months: from 0.4 to 0.8 reforms. The types of home improvements we inquired about related to flooring, plumbing, electrical installations, toilets, room remodeling, and air conditioning. Furthermore, the effect is confirmed by the $50 \%$ increase in the likelihood that the family had bought materials for home improvements in the previous six months (from $15 \%$ of households in the control group to $23 \%$ among the treated group). ${ }^{25}$

Finally, we find that the provision of street pavement had no effect on monthly per capita expenditure, i.e., non-durable consumption, measured by the sum of itemized expenditures or a direct measure of total household expenditures. ${ }^{26}$

\subsubsection{Effects on Transportation and Labor}

We now turn our attention from the impact of pavement on property values, credit, and consumer activity to its impact on transportation and labor. In the city of Acayucan, where the terrain is hilly and the precipitation substantial, many unpaved streets are impassable except by pedestrians, especially during the rainy season. For this reason, and in spite of the short period of time after paving streets, treatment may have reduced transportation costs.

We measure the impact of street pavement on transportation costs in Table 6 in terms of money and time: the cost of a taxi to the city center and the time it takes to go to the city center by one's usual means of transportation. We find that in both respects the savings for those who benefit from pavement over the control group are neither large nor statistically significant: a savings of half a peso on 18, and of one minute on 19. However our qualitative results point toward a reduction. Note that both the cost of a taxi to the city center and the

\footnotetext{
${ }^{25}$ We did not find significant changes in the stock of home quality as measured by the sum of hard floors, cement walls and cement roofing.

26 Note that we do not have financial savings measures.
} 
time it takes to go to the city center are noisy measures of transportation costs. Indeed, as was made clear by McFadden (2007), the difficulty of accurately measuring transportation costs poses a major problem for anyone attempting an empirical investigation into the role of transportation in a wide range of economic activities.

A further finding related to transportation is that household heads using motorized transportation (private, taxi, or bus) increased from $48 \%$ to $70 \%$ as a result of treatment. This fact and the possible reduction in transport costs (in terms of time and money) together prompted us to look at labor outcomes. While we find no effect on the extensive margin, we do observe an increase in the number of hours worked per week: the ITT and TOT estimates are 2.85 and 4.68 hours over a control-group average of 47 . This increase is consistent with a reduction in transportation costs and with the finding that plans on the part of a household member to migrate (in search of work) decreased by 10 percentage points, from $47 \%$ to $37 \%$. If fewer people out-migrate in search of work, the city's labor supply may increase in the long run. Finally, although reported labor supply increased in the treatment group, the increase in working hours was not reflected in an increase in reported labor income, which was, according to the TOT estimate, a statistically insignificant $4.7 \%$.

\subsubsection{Other Outcomes}

We found no evidence that pavement has an impact on health. ${ }^{27}$ We investigated this issue because we had observed that Acayucan's lack of street pavement facilitates the accumulation of garbage, generates a dusty environment during the dry season, and during the rainy season provides a fertile breeding ground in the form of stagnant water for the Aedes Aegypti mosquito, which transmits dengue fever. ${ }^{28}$ We asked individuals whether they had suffered any symptoms of disease, such as coughing, fever, and diarrhea; the self-reported

\footnotetext{
${ }^{27}$ For evidence of the impact on health of the introduction of hard floors into homes in Mexico, see Cattaneo et al. (2009).

28 There were 41,867, cases of dengue fever reported in Mexico in 2009, up from 27,479 in 2008. Of these, 7,898 were of the hemorrhagic type. Acayucan is located in Veracruz, the state with the largest number of cases of dengue fever.
} 
results of our inquiry indicated that there was no correlation between disease and pavement. Similarly, human-capital accumulation measured by enrollment in school and absenteeism among children did not vary according to whether the children lived on paved or unpaved streets (Table 6).

A few of the properties on streets in the experiment were small businesses. We attempted to assess the impact of pavement on these businesses by means of a short survey instrument regarding the number of employees, sales, and expenditures. Table A6 (business units section) reports outcomes along the intensive margin at the firm level. The results show that pavement status had no effect on the number of employees, sales, expenditures, or profits. ${ }^{29}$ Table A7 investigates whether there was an impact along the extensive margin and reports the sum of business units in 2006 and 2009 by treatment status. Although there was a greater increase in the number of business units in ITT projects than in control projects, both in absolute and in percentage terms, these differences were not borne out in terms of total employment.

We hypothesize that urban street pavement affected households but not businesses because most of the experimental streets, being in the outer areas of the city, could attract little if any consumer traffic. Moreover, because the businesses in these neighborhoods were limited, for the most part, to grocery shops, the pavement, instead of encouraging shoppers to shop locally, may have made it easier for them to go downtown to do their shopping instead. Although this finding is consistent with previous findings in developed countries, we should emphasize that our business estimates suffer from lack of power. ${ }^{30}$ Moreover, one must bear in mind that we are looking at short-term effects, whereas it may be that the effects on businesses - as on neighborhood recomposition - are long-term. ${ }^{31}$

\footnotetext{
29 To determine if positive results were being masked by a temporary negative effect in streets recently paved (due to street blockages during construction), we performed tests of differences in sales, expenditures, and profits according to an indicator for paving having taken place within the previous six months and prior to the previous six months and found no such differences.

${ }^{30}$ Haughwout (2002) shows that in the US the principal beneficiaries of infrastructure are property owners, not firms.

31 One possible negative effect of the treatment could be an increase in the crime rate, since burglars would find it easier to break into houses along paved streets. We inquired about crime victimization in terms of
} 


\subsection{Extensions}

\subsubsection{Heterogenous Effects}

Street pavement's impact may depend on the proportion of paved streets in the area in which paving takes place. On the one hand, by the law of diminishing marginal returns, private marginal returns to pavement in a given neighborhood may decrease with the number of paved streets around that neighborhood; on the other, private marginal returns to pavement may increase with the number of paved streets around that neighborhood if pavement in one street complements pavement in a contiguous paved one.

In our data, there is heterogeneity in the proportion of paved streets abutting the street projects. In particular, we note that in the central area of the city, as opposed to the outskirts, most streets were paved. In Table 7 we present separate estimates for the impact of pavement on home values for these two groups. We find that the effect of pavement is relatively high in the areas with a relatively low proportion of paved streets; i.e., when the surrounding streets are less likely to be paved, the impact of street pavement is higher. This suggests that the marginal private benefit of paving a street is higher in a low-pavement area than in a high-pavement area. This fact may be relevant for distributional concerns in pavement-allocation decisions. However, note that this does not address the question of what the socially optimal allocation of pavement in this context is. For one thing, policymakers would like to know if social returns are higher when paving some streets in all neighborhoods rather than all streets in some neighborhoods.

\subsubsection{Multiple Testing}

In any experimental evaluation with multiple outcomes, significant effects may emerge simply by chance. The larger the number of tests, the easier it is to make the mistake of thinking that there is an effect when there is none, i.e., "Type I" error. The problem is well known

burglaries and theft from (and of) vehicles but found no significant differences between the treated and the control groups. Additionally, households along paved streets and those in the control group were equally likely to feel safe while walking in their street at night (see Table A6). 
in the theoretical literature (Romano and Wolf, 2005), and it has recently received some attention in the policy evaluation literature (Kling, Liebman, and Katz, 2007; Anderson, 2008).

Multiple-testing correction procedures adjust the individual $p$-values for each outcome to keep the overall error rate to less than or equal to the user-specified $p$-value cutoff or error rate. The default correction procedure is the Benjamini and Hochberg False Discovery Rate (Benjamini and Hochberg, 1995). It is the least stringent among the standard corrections, such as Bonferroni or Holm (1979), and provides a good balance between discovery of statistically significant outcomes and limitation of false positive occurrences. We have computed False Discovery Rates (FDR) using all three adjusted $p$-values. ${ }^{32}$

Our Benjamini and Hochberg $p$-values show significant ITT and TOT effects on appraised home value, appraised land value, distance to the nearest paved street, cleanliness of the street, and household head using motor transportation to commute to work. All but the last of these measures survive the Holm (1979) and Bonferroni corrections. Note that the Bonferroni correction is the most stringent test of all, offering the most conservative approach to control for false positives. However, it does so at the cost of a very high rate of false negatives (outcomes are not statistically affected by the experiment when in reality they are). The fact that we find statistically significant effects even under the most stringent multiple-testing corrections suggests that the impacts reported in this study are not due to "Type I" errors.

\footnotetext{
32 Given $R$ outcomes and their unadjusted $p$-values, $p_{r}$ for each $r=\{1, \ldots, R\}$, Bonferroni adjusted $p$ values are calculated as $B p_{r}=\min \left\{R \cdot p_{r}, 1\right\}$. Holm adjusted $p$-values are computed by ordering the unadjusted $p$-values for the $R$ outcomes $p_{1}<p_{2}<\ldots<p_{R}$ and calculating $H p_{1}=\min \left\{R \cdot p_{1}, 1\right\}, H p_{2}=$ $\min \left\{\max \left\{H p_{1},(R-1) \cdot p_{2}\right\}, 1\right\}, H p_{3}=\min \left\{\max \left\{H p_{2},(R-2) \cdot p_{3}\right\}, 1\right\}$, etc. Finally, Benjamini and Hochberg $p$-values also order $p$-values $\left(p_{1}<p_{2}<\ldots<p_{R}\right)$ and are calculated as $B H p_{R}=p_{R}, B H p_{R-1}=$ $\min \left\{B H p_{R}, \frac{R}{(R-1)} \cdot p_{R-1}\right\}, B H p_{R-2}=\min \left\{B H p_{R}, \frac{R}{(R-2)} \cdot p_{R-2}\right\}$, etc.
} 


\section{Understanding Our Experimental Estimates}

Our experimental estimates reveal that the provision of street pavement increased the acquisition of household durable goods and motor vehicles. The increase in vehicle ownership can be rationalized via the complementarity with street pavement and also by means of wealth effects arising from the increase in property values. However, the increase in the acquisition of household durable goods can only be understood a wealth effect.

Given that we did not find clear evidence of increases in productivity - we do not observe increases in either wages or labor income - the increase in durable-goods consumption must be due to increased credit use. In this section we present evidence consistent with the view that access to banking services was crucial in transforming the increase in property values into durable-goods consumption.

If the access-to-banking mechanism is operating, we should observe that pavement increased collateral-based credit use among households who had access to banking services but not among those without it. Similarly, we should find that pavement increased the acquisition of durable goods and vehicle ownership among households who had access to banking services but not among those without it.

We present evidence for this hypothesis in Table 8, where access to banking services is measured by whether someone in the household had a bank account in 2006, before the intervention. The table contains two panels. In the top panel we estimate ITT effects, while in the bottom one we estimate TOT effects. The first three columns focus on credit, while the last three columns look at durable goods (including vehicles).

We start in the top panel by splitting the sample into households with and without access to banking services and estimate ITT effects on household collateral-based credit use

in columns 1 and 2, and on household durable goods in columns 4 and 5. In columns 3 and 6 we estimate the following reduced-form equation:

$$
Y_{2009}=\pi_{0}+\pi_{1} Z+\pi_{2} X+\pi_{3} Z X+\pi_{4} Y_{2006}+\epsilon_{4}
$$


where $X$ is an indicator of the household's having a bank account in 2006, and the rest of the variables are defined as in equation (1). In equation (2), $\pi_{1}$ measures the ITT for all households, $\pi_{2}$ captures differences in the outcome in 2009 associated with having a banking account in 2006, and $\pi_{3}$ is the difference in the ITT effect between households with a bank account and those without one. If our explanation is valid, we should find evidence that $\pi_{1}=0$ and that $\pi_{3}>0$.

In the bottom panel, we split the sample again, and estimate TOT effects on household collateral-based credit use in columns 1 and 2, and on household durable goods in columns 4 and 5 . In columns 3 and 6 we estimate by 2SLS the following equation:

$$
Y_{2009}=\theta_{0}+\theta_{1} D+\theta_{2} X+\theta_{3} D X+\theta_{4} Y_{2006}+\epsilon_{5}
$$

where we use pavement-group assignment $Z$ and its interaction with bank account in $2006(Z X)$ as instrumental variables for the street's being paved $D$ and its interaction with a bank account in $2006(D X)$. As long as the relationship is linear, evidence that $\theta_{1}=0$ and $\theta_{3}>0$ would confirm our explanation, no TOT effects for households without banking account, but positive TOT effects for households with a bank account.

The first two columns in Table 8 show that the increase in collateral-based credit use due to assignment-to-pavement (ITT) and pavement (TOT) was concentrated among households who had a bank account as of 2006. The third column estimates the interaction effect in a single regression with the full sample, equation (2) in the top panel, and equation (3) in the bottom panel. Only the interaction between assignment-to-pavement (or pavement) and bank account in 2006 is significant. Similarly, in columns 4 and 5, the effect on durablegoods acquisition is estimated separately for the sample with and without access to banking services as of 2006. The coefficients show that only those households with access to banking services accumulated more durable goods once their street had been paved. This is confirmed in column 6 , which estimates the interaction effect in a single regression with the full sample (reduced form and 2SLS, in the top and bottom panels, respectively). 
Table 8 demonstrates the existence of differential ITT and TOT effects for credit use and durable-goods acquisition across households depending on whether they had a bank account in 2006. These results provide strong support for the hypothesis that in order to transform the increase in property values derived from street pavement into durable-goods consumption, households need to have access to the banking sector. ${ }^{33}$

\section{The Private Gains from Street Pavement}

If private benefits outweigh construction costs, property taxation may provide a viable avenue for financing this type of urban infrastructure. Thus the finding of large returns to property owners prompts a comparison of construction costs with the sum of increases in land value for properties along paved streets.

We measure construction costs as the sum of municipal expenditures on each street that got paved. Specifically, the municipality reported that the total cost of paving the streets in this study amounted to 11,304, 642 pesos. Following Jacoby (2000), and drawing on the professional appraisals, we calculate the benefit to the owners of plots that benefited from the paving project as the sum of increases in their value over that of plots on previously paved streets. ${ }^{34}$

Table 9 reports the results of our analysis. There were 814 plots on streets that got paved. The average plot on these streets was valued at 27,844 pesos. Multiplying this value by the estimated impact of street pavement (54\%) gives an average benefit per plot of 15,081 pesos, for a total private benefit of $12,275,585$ pesos. The last column shows that the increases in land values represent $109 \%$ of construction costs.

Note that our calculation explicitly refers to private gains reflected in land values. This is not a full cost-benefit analysis because we are not accounting for possible externalities of street pavement (see Rossi-Hansberg, Sarte, and Owens III, 2010). Likewise, we are ignoring

\footnotetext{
33 This does not rule out that access to the banking sector may indicate financial knowledge or other characteristics of the household.

${ }^{34}$ An alternative strategy can be found in Kaufman and Quigley (1987).
} 
the deadweight losses that would be generated by taxation. ${ }^{35}$

\section{Conclusion}

Basic infrastructure is necessary for the adequate functioning of any economy. Despite an extensive effort in economics to analyze the effects of many types of infrastructure, endogeneity bias has always been a concern; it is difficult to refute the argument that comparisons of places with and without infrastructure that are based on observational data can be misleading.

In order to bridge this gap in the literature, we designed a unique street-pavement experiment in Mexico, the first to resolve the problem of selection bias inherent in infrastructure placement using random assignment, and estimated positive experimental effects on home and land values, the use of collateral-based credit, and the consumption of durable goods. The impact of street-pavement provision on home prices is estimated to be between $16 \%$ and $25 \%$, and on land values around $54 \%$. Individual collateral-based credit increased from $2 \%$ (control group) to $5 \%$ (treatment group). Street paving increased the number of durable goods owned by a household, from 2.4 to around 2.7, out of a total of six categories of durable goods, as well as vehicle ownership, from 0.25 to 0.35 , out of three possible motorized vehicles. The magnitudes of these effects are considerable, taking into account the short-term nature of our evaluation.

What is the mechanism behind these experimental estimates? We argue that households on paved streets can acquire more household durable goods, as well as vehicles, because pavement increases the use of collateral-based credit (and its amount), through the increase in their home/land values, as long as they have access to banking services. Without access to banking services, households cannot benefit from the increase in home values (due to street pavement) in terms of collateral-based credit, and as a consequence they cannot acquire more durable goods and vehicles. Our data provide strong evidence for this mediating channel.

\footnotetext{
${ }^{35}$ See Warlters and Auriol (2005) for estimates of the marginal cost of public funds in developing countries.
} 
Weighing the increase in the value of land plots on paved streets against the municipality expenditures on each street-pavement project, we obtain an estimated private-gains-to-costs ratio equal to 1.09. This positive ratio persuades us that the use of property taxation to finance local public infrastructure is a fertile field for future research.

What can we learn from this study? Public infrastructure, such as street pavement, has a major impact on the value of a home, which in developing countries is perhaps the most important of household assets, and on durable-goods consumption and vehicle ownership, important indicators of a household's well-being. Even more importantly, we also found evidence that households must have access to the banking system in order to fully benefit from infrastructure investments. If they do not, it is unlikely that infrastructure will be transformed into credit use and the acquisition of durable goods. Finally, this paper illustrates how a research collaboration with a municipal government can allow for an experimental analysis of public-infrastructure provision. In that sense, our findings encourage the replication of experimental infrastructure evaluations in other contexts. This would reveal to what extent the observed causal effects in Acayucan are externally valid. If they are, the implications for the provision of local public infrastructure at the municipal level are of worldwide significance. 


\section{References}

Aghion, P., And P. Bolton (1997): "A Theory of Trickle-Down Growth and Development," Review of Economic Studies, 64(2), 151-172.

Anderson, M. L. (2008): "Multiple Inference and Gender Differences in the Effects of Early Intervention: A Reevaluation of the Abecedarian, Perry Preschool, and Early Training Projects," Journal of the American Statistical Association, 103(484), 1481-1495.

Angrist, J. D., G. W. Imbens, And D. Rubin (1996): "Identification of Causal Effects Using Instrumental Variables," Journal of the American Statistical Association, 91(434), $444-472$.

Banerjee, A. (2004): Contracting Constraints, Credit Markets and Economic DevelopmentAdvances in economics and econometrics: Theory and applications. Cambridge: Cambridge University Press.

Banerjee, A. V., And E. Duflo (2007): "The Economic Lives of the Poor," Journal of Economic Perspectives, 21(1), 141-167.

Banerjee, A. V., And A. F. Newman (1993): "Occupational Choice and the Process of Development," Journal of Political Economy, 101(2), 274-298.

Benjamini, Y., And Y. Hochberg (1995): "Controlling the False Discovery Rate: a Practical and Powerful Approach to Multiple Testing," Journal of the Royal Statistical Society, Series B (Methodological), 57(1), 289-300.

Bloom, H. S. (1984): "Accounting for No-Shows in Experimental Evaluation Designs," Evaluation Review, 8(2), 225-246.

Brown, J. N., And H. S. Rosen (1982): "On the Estimation of Structural Hedonic Price Models," Econometrica, 50(3), 765-768. 
Brueckner, J. K. (1982): "A Test for Allocative Efficiency in the Local Public Sector," Journal of Public Economics, 19(3), 311-331.

Bucks, B., And K. Pence (2006): "Do Homeowners Know Their House Values and Mortgage Terms?," FEDS Working Paper, (2006-03).

Burgess, R., And R. Pande (2005): "Do Rural Banks Matter? Evidence from the Indian Social Banking Experiment," American Economic Review, 95(3), 780-795.

Burgess, R., R. Pande, and G. Wong (2005): "Banking for the poor: evidence from India," Journal of the European Economic Association, 3(2-3), 268-278.

Case, K. E., and R. Shiller (1987): "Prices of Single-Family Homes Since 1970: New Indexes for four Cities," New England Economic Review, (Sep), 45-56.

Cattaneo, M. D., S. Galiani, P. J. Gertler, S. Martinez, and R. Titiunik (2009): "Housing, Health, and Happiness," American Economic Journal: Economic Policy, 1(1), $75-105$.

Cellini, S. R., F. Ferreira, and J. Rothstein (2010): "The Value of School Facility Investments: Evidence from a Dynamic Regression Discontinuity Design," Quarterly Journal of Economics, 125(1), 215-261.

Deaton, A. (1997): The Analysis of Household Surveys. A Microeconometric Approach to Development Policy. John Hopkins University Press.

(2009): "Instruments of Development: Randomization in the Tropics, and the Search for the Elusive Keys to Economic Development," Keynes Lecture in Economics: Proceedings of the British Academy, 162, 123-160.

Dinkelman, T. (2008): "The Effects of Rural Electrification on Employment: New Evidence from South Africa," mimeo, Princeton University. 
Donaldson, D. (2010): "Railroads of the Raj: Estimating the Impact of Transportation Infrastructure," NBER Working Paper, 16487.

Duflo, E., And R. PAnde (2007): "Dams," Quarterly Journal of Economics, 122(2), 601-646.

Field, E., And M. Torero (2004): "Do Property Titles Increase Credit Access Among the Urban Poor?," Working Paper.

Gertler, P. (2004): "Do Conditional Cash Transfers Improve Child Health? Evidence from PROGRESA's Control Randomized Experiment," American Economic Review Papers and Proceedings, 94(2), 336-341.

Gonzalez-Navarro, M., and C. Quintana-Domeque (2009): "The Reliability of SelfReported Home Values in a Developing Country Context," Journal of Housing Economics, $18(4), 311-324$.

_ (2010): "Description of the Acayucan Standards of Living Survey," Working Paper.

Goodman, J., and J. ItTner (1992): "The Accuracy of Home Owners' Estimates of House Value," Journal of Housing Economics, 2(4), 339-357.

Haughwout, A. F. (2002): "Public infrastructure investments, productivity and welfare in fixed geographic areas," Journal of Public Economics, 83(3), 405-428.

Henderson, V. (2002): "Urbanization in Developing Countries," World Bank Research Observer, 17(1), 89-112.

Holm, S. (1979): "A Simple Sequentially Rejective Bonferroni Test Procedure," Scandinavian Journal of Statistics, 6, 65-70.

INEGI, CONAPO, SEGOB, AND SEDESOL (2007): Delimitación de las zonas Metropolitanas de México 2005. 
Jacoby, H. G. (2000): "Access to Markets and the Benefits of Rural Roads," Economic Journal, 110(465), 713-737.

Jimenez, E. (1982): "The Value of Squatter Dwellings in Developing Countries," Economic Development and Cultural Change, 30(4), 739-752.

Kain, J., AND J. Quigley (1972): “Note on Owner's Estimate of Housing Value,” Journal of the American Statistical Association, 67(340), 803-806.

Kanemoto, Y. (1988): "Hedonic Prices and the Benefits of Public Policies," Econometrica, 56(4), 981-989.

Kaufmann, D., And J. M. Quigley (1987): "The Consumption Benefits of Investment in Infrastructure: The Evaluation of Sites-and-Services Programs in Underdeveloped Countries," Journal of Development Economics, 25(2), 263-284.

Kiel, K. A., And J. E. Zabel (1999): "The Accuracy of Owner-Provided House Values: The 1978-1991 American Housing Survey," Real Estate Economics, 27(2), 263-298.

Kish, L., And J. LAnsing (1954): "Response Errors in Estimating the Value of Homes," Journal of the American Statistical Association, 49(267), 520-538.

Kling, J. R., J. B. Liebman, and L. F. Katz (2007): "Experimental Analysis of Neighborhood Effects," Econometrica, 75(1), 83-119.

List, J. A., S. Sadoff, And M. Wagner (2009): "So you want to run an experiment, now what? Some Simple Rules of Thumb for Optimal Experimental Design," Carlo Alberto Working Papers Series, (125).

McFAdDen, D. (2007): "The behavioral science of transportation," Transport Policy, 14(4), 269-274. 
NAPIER, M. (2009): Making Urban Land Markets Work Better in South African Cities and Towns: Arguing the Basis for Access by the Poorin Lall, Freire, Yuen, Rajack, Helluin: "Urban Land Markets: Improving Land Management for Successful Urbanization". Springer Netherlands.

Romano, J., And M. Wolf (2005): “Stepwise Multiple Testing as Formalized Data Snooping," Econometrica, 73(4), 1237-1282.

Rosen, S. (1974): "Hedonic Prices and Implicit Markets: Product Differentiation in Pure Competition," Journal of Political Economy, 82(1), 34-55.

Rossi-Hansberg, E., P. D. Sarte, and R. Owens III (2010): "Housing Externalities," Journal of Political Economy, 118(3), 485-535.

Skoufias, E. (2001): "PROGRESA and its Impacts on the Human Capital and Welfare of Households in Rural Mexico: A Synthesis of the Results of an Evaluation by IFPRI," International Food Policy Research Institute Working Paper.

UN-Habitat (2003): The Challenge of Slums - Global Report on Human Settlements. UNHabitat.

VAn DE Walle, D. (2002): "Choosing Rural Road Investments to Help Reduce Poverty," World Development, 30(4), 575-589.

Wartlers, M., And E. Auriol (2005): "The Marginal Cost of Public Funds in Africa," World Bank Policy Research Working Paper.

Welch, B. L. (1947): "The Generalization of 'Student's' Problem when Several Different Population Variances are Involved," Biometrika, 34(1/2), 28-35.

World BANK (1994): "World Development Report 1994 : Infrastructure for Development," Washington D.C. World Bank. 


\section{Figures}

Figure 1: Acayucan Street Projects

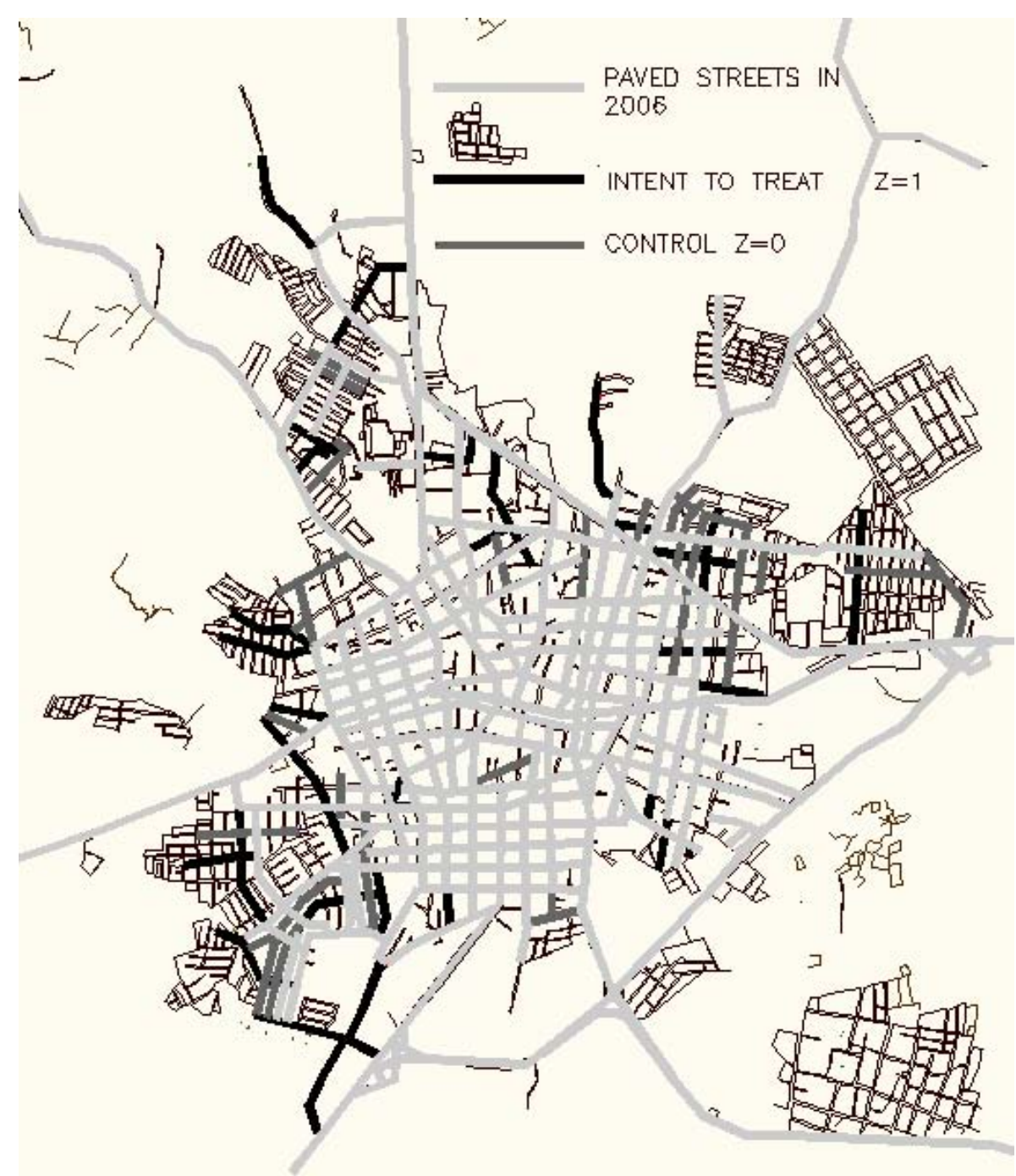


Figure 2: Before Pavement Example

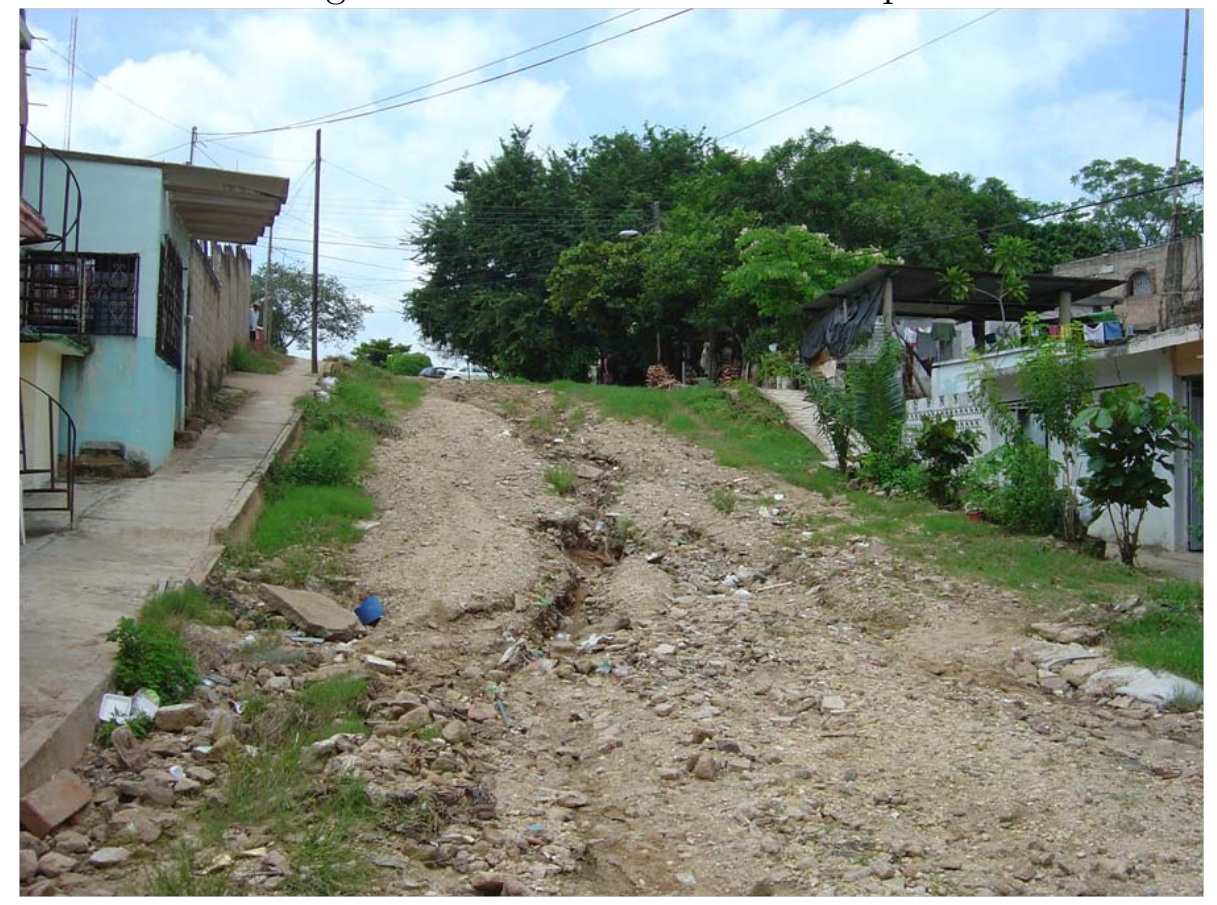

Figure 3: After Pavement Example

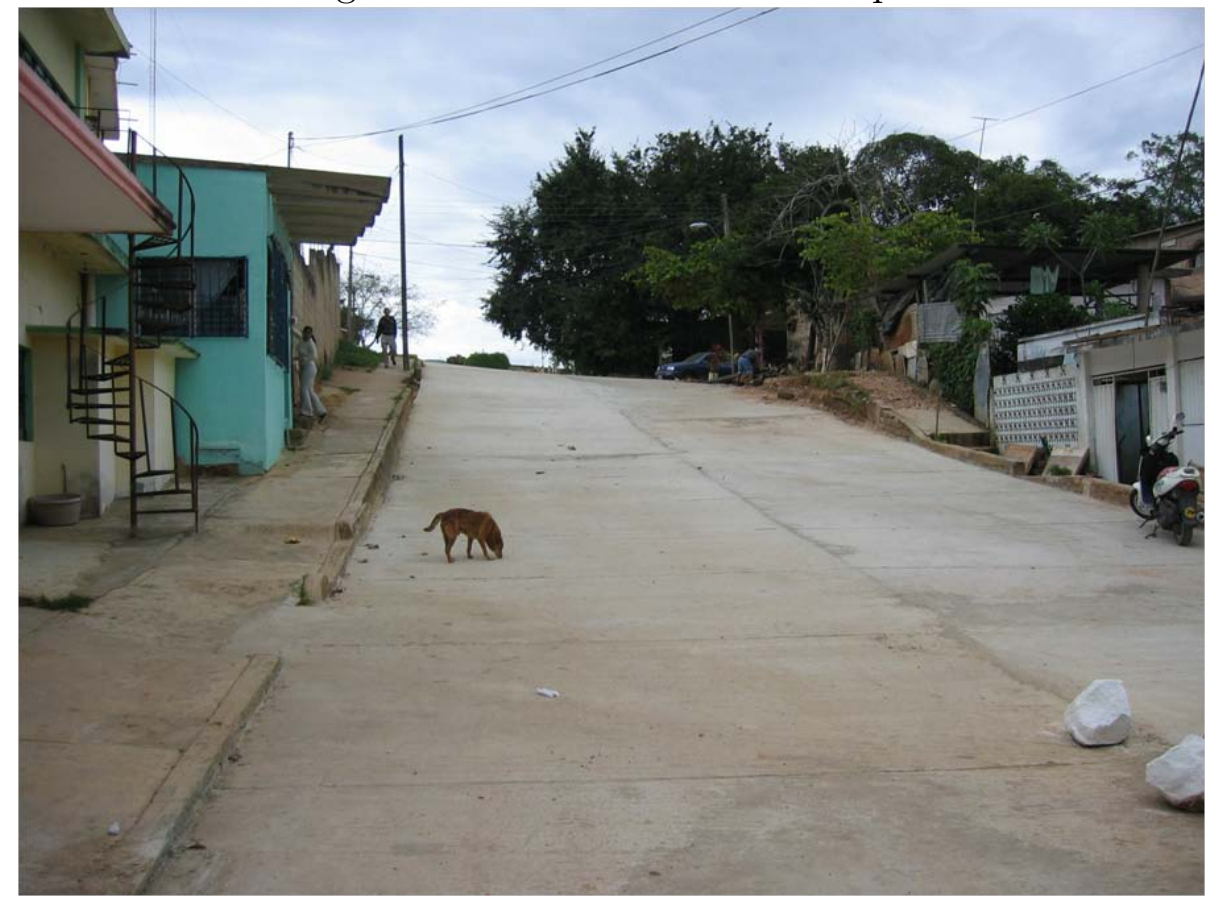


Figure 4: Change in House Value in Control Group

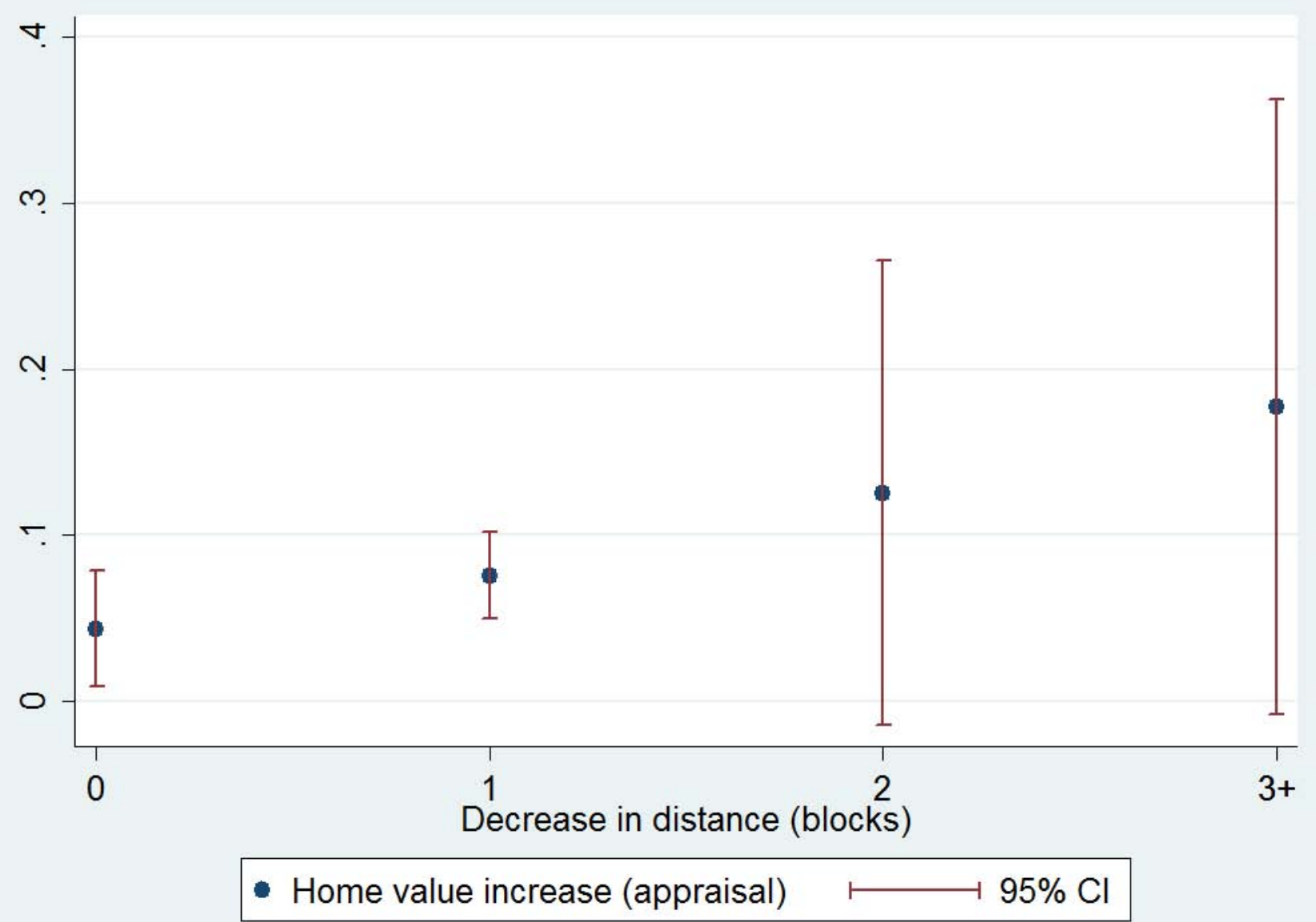

The figure uses the estimates from a regression of the change in home value on a constant and three indicator variables of change in distance (1 block, 2 , blocks, $3+$ blocks) in the control group. 


\section{Tables}

Table 1: Comparison to City

\begin{tabular}{lcc}
\hline \hline Individual Level Variables & $\begin{array}{c}\text { Acayucan } \\
(2005 \text { Census }\end{array}$ & $\begin{array}{c}\text { Experimental Streets } \\
\text { (ASLS 2006) }\end{array}$ \\
\hline Population & 49,945 & 9,088 \\
Male/Female Ratio & $89 \%$ & $89 \%$ \\
Share Aged 0-5 & $11 \%$ & $11 \%$ \\
Share Aged 65+ & $6 \%$ & $5 \%$ \\
Illiterate (Age 15+) & $9 \%$ & $11 \%$ \\
Enrolled in School (Age 6-14) & $96 \%$ & $96 \%$ \\
Enrolled in School (Age 12-14) & $94 \%$ & $93 \%$ \\
Enrolled in School (Age 15-24) & $48 \%$ & $48 \%$ \\
& & \\
Household Level Variables & & 2,264 \\
\hline Families & 12,874 & 2,197 \\
Dwellings & 12,693 & $27 \%$ \\
1 Room Dwelling & $22 \%$ & $36 \%$ \\
2 Room Dwelling & $17 \%$ & $37 \%$ \\
3+ Room Dwelling & $60 \%$ & $21 \%$ \\
No Tap Water in Lot & $16 \%$ & $98 \%$ \\
Electricity & $98 \%$ & $80 \%$ \\
Refrigerator & $81 \%$ & $52 \%$ \\
Washing Machine & $55 \%$ & $11 \%$ \\
Computer & $14 \%$ & \\
\hline \hline
\end{tabular}

Column 1 consists of data from locality census (Conteo 2005, INEGI). Column 2 consists of weighted data from baseline Acayucan Standards of Living Survey 2006. 
Table 2: Pre-Intervention Balance in Means

\begin{tabular}{|c|c|c|c|c|c|c|c|}
\hline Variable & $\mathrm{ITT}=1$ & $\mathrm{ITT}=0$ & Diff. & Variable & $\mathrm{ITT}=1$ & $\mathrm{ITT}=0$ & Diff. \\
\hline Housing & & & & Consumption (continued) & & & \\
\hline $\begin{array}{l}\text { Nearest paved street } \\
\text { (street blocks) }\end{array}$ & $\begin{array}{l}1.49 \\
(0.16) \\
{[487]}\end{array}$ & $\begin{array}{l}1.35 \\
(0.15) \\
{[411]}\end{array}$ & $\begin{array}{c}0.13 \\
(0.22) \\
{[898]}\end{array}$ & $\begin{array}{l}\text { Sum of durable } \\
\text { goods }(0-6)\end{array}$ & $\begin{array}{c}2.12 \\
(0.163) \\
{[487]}\end{array}$ & $\begin{array}{c}2.04 \\
(0.075) \\
{[413]}\end{array}$ & $\begin{array}{c}0.08 \\
(0.178) \\
{[900]}\end{array}$ \\
\hline $\begin{array}{l}\text { Log owner estimate } \\
\text { of house price }\end{array}$ & $\begin{array}{l}11.75 \\
(0.12) \\
{[269]}\end{array}$ & $\begin{array}{l}11.81 \\
(0.10) \\
{[262]}\end{array}$ & $\begin{array}{l}-0.06 \\
(0.15) \\
{[531]}\end{array}$ & $\begin{array}{l}\text { Vehicles (car/truck/motorcycle) } \\
(0-3)\end{array}$ & $\begin{array}{c}0.203 \\
(0.050) \\
{[487]}\end{array}$ & $\begin{array}{c}0.226 \\
(0.033) \\
{[413]}\end{array}$ & $\begin{array}{c}-0.023 \\
(0.059) \\
{[900]}\end{array}$ \\
\hline $\begin{array}{l}\text { Log professional } \\
\text { appraisal property }\end{array}$ & $\begin{array}{l}11.64 \\
(0.08) \\
{[295]}\end{array}$ & $\begin{array}{l}11.60 \\
(0.05) \\
{[253]}\end{array}$ & $\begin{array}{c}0.04 \\
(0.10) \\
{[548]}\end{array}$ & $\begin{array}{l}\text { Home improvements } \\
(0-11)\end{array}$ & $\begin{array}{c}0.541 \\
(0.048) \\
{[487]}\end{array}$ & $\begin{array}{c}0.474 \\
(0.054) \\
{[413]}\end{array}$ & $\begin{array}{c}0.067 \\
(0.071) \\
{[900]}\end{array}$ \\
\hline $\begin{array}{l}\text { Log professional } \\
\text { appraisal land }\end{array}$ & $\begin{array}{l}10.27 \\
(0.07) \\
{[295]}\end{array}$ & $\begin{array}{l}10.14 \\
(0.05) \\
{[253]}\end{array}$ & $\begin{array}{l}0.13 \\
(0.09) \\
{[548]}\end{array}$ & $\begin{array}{l}\text { Bought materials } \\
\text { for home improvement }(=1)\end{array}$ & $\begin{array}{c}0.254 \\
(0.022) \\
{[485]}\end{array}$ & $\begin{array}{c}0.219 \\
(0.020) \\
{[409]}\end{array}$ & $\begin{array}{c}0.035 \\
(0.029) \\
{[894]}\end{array}$ \\
\hline Log rent & $\begin{array}{c}6.48 \\
(0.13) \\
{[34]}\end{array}$ & $\begin{array}{l}6.50 \\
(0.11) \\
{[22]}\end{array}$ & $\begin{array}{c}-0.03 \\
(0.17) \\
{[56]}\end{array}$ & $\begin{array}{l}\text { Labor and Transportation } \\
\text { Weekly hours } \\
\text { worked (i) }\end{array}$ & $\begin{array}{l}48.35 \\
(1.44)\end{array}$ & $\begin{array}{l}47.70 \\
(1.16)\end{array}$ & $\begin{array}{c}0.65 \\
(1.83)\end{array}$ \\
\hline Credit & & & & & {$[481]$} & {$[411]$} & {$[892]$} \\
\hline $\begin{array}{l}\text { Collateral-based } \\
\text { credit }(=1) \text { (i) }\end{array}$ & $\begin{array}{c}0.031 \\
(0.006) \\
{[961]}\end{array}$ & $\begin{array}{c}0.031 \\
(0.007) \\
{[844]}\end{array}$ & $\begin{array}{l}0.000 \\
(0.009) \\
{[1,805]}\end{array}$ & $\begin{array}{l}\text { Monthly log labor } \\
\text { income (1) }\end{array}$ & $\begin{array}{c}7.99 \\
(0.081) \\
{[398]}\end{array}$ & $\begin{array}{c}7.82 \\
(0.049) \\
{[367]}\end{array}$ & $\begin{array}{c}0.17^{*} \\
(0.094) \\
{[765]}\end{array}$ \\
\hline $\begin{array}{l}\text { Collateral-based } \\
\text { credit amount(i) }\end{array}$ & $\begin{array}{l}716 \\
(292) \\
{[961]}\end{array}$ & $\begin{array}{l}476 \\
(168) \\
{[844]}\end{array}$ & $\begin{array}{c}240 \\
(334) \\
{[1,805]}\end{array}$ & $\begin{array}{l}\text { Plans to migrate } \\
\text { in search of work }(=1)\end{array}$ & $\begin{array}{c}0.410 \\
(0.030) \\
{[431]}\end{array}$ & $\begin{array}{c}0.417 \\
(0.022) \\
{[370]}\end{array}$ & $\begin{array}{c}-0.007 \\
(0.037) \\
{[801]}\end{array}$ \\
\hline $\begin{array}{l}\text { Non-collateral } \\
\text { based credit }(=1) \text { (1) }\end{array}$ & $\begin{array}{c}0.053 \\
(0.008) \\
{[961]}\end{array}$ & $\begin{array}{c}0.038 \\
(0.007) \\
{[844]}\end{array}$ & $\begin{array}{l}0.015 \\
(0.010) \\
{[1,805]}\end{array}$ & $\begin{array}{l}\text { Household head motor } \\
\text { transport to work(i) }\end{array}$ & $\begin{array}{c}0.64 \\
(0.048) \\
{[171]}\end{array}$ & $\begin{array}{c}0.55 \\
(0.060) \\
{[109]}\end{array}$ & $\begin{array}{c}0.09 \\
(0.076) \\
{[280]}\end{array}$ \\
\hline $\begin{array}{l}\text { Non-collateral based } \\
\text { credit amount(i) }\end{array}$ & $\begin{array}{l}534 \\
(143) \\
{[961]}\end{array}$ & $\begin{array}{l}263 \\
(82) \\
{[844]}\end{array}$ & $\begin{array}{c}271 \\
(164) \\
{[1,805]}\end{array}$ & $\begin{array}{l}\text { Cost of taxi to } \\
\text { city center }\end{array}$ & $\begin{array}{c}20.66 \\
(0.909) \\
{[482]}\end{array}$ & $\begin{array}{c}20.21 \\
(0.820) \\
{[407]}\end{array}$ & $\begin{array}{l}0.449 \\
(1.21) \\
{[889]}\end{array}$ \\
\hline $\begin{array}{l}\text { Credit from family } \\
\text { and friends }(=1) \text { (i) }\end{array}$ & $\begin{array}{c}0.006 \\
(0.003) \\
{[961]}\end{array}$ & $\begin{array}{c}0.005 \\
(0.003) \\
{[844]}\end{array}$ & $\begin{array}{c}0.001 \\
(0.004) \\
{[1,805]}\end{array}$ & $\begin{array}{l}\text { Time to city center } \\
\text { (minutes) }\end{array}$ & $\begin{array}{c}19.90 \\
(0.947) \\
{[487]}\end{array}$ & $\begin{array}{c}20.86 \\
(0.890) \\
{[412]}\end{array}$ & $\begin{array}{c}-0.963 \\
(1.29) \\
{[899]}\end{array}$ \\
\hline $\begin{array}{l}\text { Informal private } \\
\text { credit }(=1) \text { (i) }\end{array}$ & $\begin{array}{c}0.003 \\
(0.002) \\
{[961]}\end{array}$ & $\begin{array}{c}0.008 \\
(0.003) \\
{[844]}\end{array}$ & $\begin{array}{l}-0.005 \\
(0.003) \\
{[1,805]}\end{array}$ & $\frac{\text { Health }}{\text { Sick previous } \operatorname{month}(=1) \text { (i) }}$ & $\begin{array}{c}0.485 \\
(0.020)\end{array}$ & $\begin{array}{c}0.472 \\
(0.023)\end{array}$ & $\begin{array}{c}0.013 \\
(0.030)\end{array}$ \\
\hline Bank account $(=1)$ & $\begin{array}{c}0.154 \\
(0.030) \\
{[481]}\end{array}$ & $\begin{array}{c}0.166 \\
(0.018) \\
{[410]}\end{array}$ & $\begin{array}{c}-0.012 \\
(0.035) \\
{[891]}\end{array}$ & $\begin{array}{l}\text { Fungus, parasites skin } \\
\text { infections }(=1) \text { (i) }\end{array}$ & $\begin{array}{c}{[1,707]} \\
0.140 \\
(0.015)\end{array}$ & $\begin{array}{c}{[1,445]} \\
0.170 \\
(0.016)\end{array}$ & $\begin{array}{l}{[3,152]} \\
-0.030 \\
(0.022)\end{array}$ \\
\hline Credit card $(=1)$ & $\begin{array}{c}0.097 \\
(0.026)\end{array}$ & $\begin{array}{c}0.087 \\
(0.012)\end{array}$ & $\begin{array}{c}0.010 \\
(0.028)\end{array}$ & Schooling (Ages 5-17) & {$[1,701]$} & {$[1,444]$} & {$[3,145]$} \\
\hline Consumption & {$[480]$} & {$[410]$} & {$[890]$} & $\overline{\text { School enrollment }(=1)(1)}$ & $\begin{array}{c}0.956 \\
(0.009)\end{array}$ & $\begin{array}{c}0.957 \\
(0.012)\end{array}$ & $\begin{array}{l}-0.001 \\
(0.015)\end{array}$ \\
\hline $\begin{array}{l}\text { Monthly log per } \\
\text { capita expenditure }\end{array}$ & $\begin{array}{c}6.77 \\
(0.073) \\
{[461]}\end{array}$ & $\begin{array}{c}6.69 \\
(0.050) \\
{[403]}\end{array}$ & $\begin{array}{c}0.08 \\
(0.087) \\
{[864]}\end{array}$ & $\begin{array}{l}\text { Absenteeism previous } \\
\text { month }(=1) \text { (i) }\end{array}$ & $\begin{array}{c}{[496]} \\
0.188 \\
(0.018)\end{array}$ & $\begin{array}{c}{[402]} \\
0.175 \\
(0.027)\end{array}$ & $\begin{array}{c}{[898]} \\
0.013 \\
(0.032)\end{array}$ \\
\hline $\begin{array}{l}\text { Monthly log sum of } \\
\text { itemized expenditures } \\
\text { per capita }\end{array}$ & $\begin{array}{c}6.60 \\
(0.079) \\
{[474]}\end{array}$ & $\begin{array}{c}6.49 \\
(0.045) \\
{[409]}\end{array}$ & $\begin{array}{c}0.11 \\
(0.090) \\
{[883]}\end{array}$ & & {$[421]$} & {$[322]$} & {$[743]$} \\
\hline
\end{tabular}

(1) denotes individual-level outcomes. Means use survey weights. Standard errors clustered at the pavement-project level in parentheses. Number of observations in brackets. Individual variables regarding credit and labor outcomes for individuals aged 18-65. Variable definitions: Nearest paved street (distance in blocks from the dwelling to the nearest paved street); collateral-based credit (mortgages, home-equity lines, and collateralized bank loans); non-collateralized credit (appliance- and furniture-store credit, bank-card credit, vehicle loans, and casas de crdito popular); informal credit (credit from informal lenders); credit card (bank account): indicator that someone in the household has a credit card (bank account); monthly log per capita expenditure (based on total self-reported expenditure in the household); monthly log sum of itemized expenditures per capita (based on the sum of household expenditures on food, phone, gas, electricity, education, rent/mortgage, clothes, and entertainment); sum of durable goods (sum of indicators for refrigerator, washing machine, microwave oven, air conditioning, video player, and computer); vehicles (sum of indicators for car, truck, and motorcycle); home improvements (sum of indicators for improvements in flooring, walls, roofing, sewerage connection, plumbing, toilets, electrical installations, room construction, remodeling, security measures, and improvements to house front); materials purchased for home improvements (in the previous 6 months); weekly hours worked (in the previous week); plans to migrate in search of work (if someone in the household is expected to migrate in search of work); household-head motor transportation to work (if household head uses motorized transportation, such as taxi, bus, or own vehicle, to commute to and from work); cost of taxi to city center (self-reported cost of a taxi from home to city center); time to city center (self-reported time to commute from home to city center); sick previous month (self-reported symptoms: cough, flu, diarrhea, etc.), absenteeism previous month (if child missed at least one school day in the previous month). Significance levels reported only for Diff: $*$ significant at $10 \%$; $*$ significant at $5 \%$; $* * *$ significant at $1 \%$. 
Table 4: Effect of Street Pavement on Credit Use

\begin{tabular}{|c|c|c|c|}
\hline & ITT & TOT & Mean Control (2009) \\
\hline \multirow{3}{*}{ Collateral-based credit (=1) (i) } & $0.018^{*}$ & $0.030^{*}$ & 0.020 \\
\hline & $(0.010)$ & $(0.016)$ & $(0.005)$ \\
\hline & {$[1,805]$} & {$[1,805]$} & {$[844]$} \\
\hline \multirow[t]{3}{*}{ Collateral-based credit amount(i) } & $992^{*}$ & $1,651^{*}$ & 150 \\
\hline & $(557)$ & $(848)$ & $(51)$ \\
\hline & {$[1,805]$} & {$[1,805]$} & {$[844]$} \\
\hline \multirow[t]{3}{*}{ Non-collateral based credit (=1) i) } & -0.002 & -0.004 & 0.075 \\
\hline & $(0.013)$ & $(0.022)$ & $(0.010)$ \\
\hline & {$[1,805]$} & {$[1,805]$} & {$[844]$} \\
\hline \multirow[t]{3}{*}{ Non-collateral based credit amount(i) } & 252 & 420 & 887 \\
\hline & $(393)$ & $(648)$ & $(232)$ \\
\hline & {$[1,805]$} & {$[1,805]$} & {$[844]$} \\
\hline \multirow[t]{3}{*}{ Credit from family and friends $(=1)$ (i) } & 0.001 & 0.002 & 0.004 \\
\hline & $(0.003)$ & $(0.005)$ & $(0.002)$ \\
\hline & {$[1,805]$} & {$[1,805]$} & {$[844]$} \\
\hline \multirow[t]{3}{*}{ Informal private credit (=1) (i) } & 0.001 & 0.001 & 0.002 \\
\hline & $(0.002)$ & $(0.004)$ & $(0.002)$ \\
\hline & {$[1,805]$} & {$[1,805]$} & {$[844]$} \\
\hline \multirow[t]{3}{*}{ Credit card $(=1)$} & 0.033 & 0.055 & 0.155 \\
\hline & $(0.032)$ & $(0.052)$ & $(0.021)$ \\
\hline & {$[890]$} & {$[890]$} & {$[410]$} \\
\hline \multirow[t]{3}{*}{ Bank account $(=1)$} & 0.043 & 0.071 & 0.138 \\
\hline & $(0.027)$ & $(0.045)$ & $(0.020)$ \\
\hline & {$[891]$} & {$[891]$} & {$[410]$} \\
\hline
\end{tabular}

(i) denotes individual-level outcomes. ITT column uses assignment to pavement as independent variable. TOT column instruments pavement with assignment to pavement. Regressions include a constant and the corresponding lagged dependent variable. Estimation takes survey weights into account. Standard errors clustered at the pavement-project level in parentheses. Number of observations in brackets. Significance levels reported only for ITT and TOT: * significant at $10 \%$; ** significant at $5 \%$; *** significant at $1 \%$. 
Table 5: Effect of Street Pavement on Consumption

\begin{tabular}{|c|c|c|c|}
\hline & ITT & TOT & Mean Control (2009) \\
\hline Sum of durable & $0.166^{*}$ & $0.274^{*}$ & 2.36 \\
\hline \multirow[t]{2}{*}{ goods $(0-6)$} & $(0.091)$ & $(0.147)$ & $(0.077)$ \\
\hline & {$[900]$} & {$[900]$} & {$[413]$} \\
\hline \multirow[t]{3}{*}{ Vehicles (car/truck/motorcycle) (0-3) } & $0.063^{*}$ & $0.104^{*}$ & 0.245 \\
\hline & $(0.037)$ & $(0.059)$ & $(0.027)$ \\
\hline & {$[900]$} & {$[900]$} & {$[413]$} \\
\hline \multirow[t]{3}{*}{ Home improvements $(0-11)$} & $0.258^{* *}$ & $0.424^{* *}$ & 0.400 \\
\hline & $(0.112)$ & $(0.202)$ & $(0.064)$ \\
\hline & {$[900]$} & {$[900]$} & {$[413]$} \\
\hline Materials purchased & $0.052^{*}$ & $0.086^{*}$ & 0.146 \\
\hline \multirow[t]{2}{*}{ for home improvement $(=1)$} & $(0.027)$ & $(0.046)$ & $(0.021)$ \\
\hline & {$[894]$} & {$[894]$} & {$[409]$} \\
\hline Monthly log per & 0.047 & 0.077 & 6.73 \\
\hline \multirow[t]{2}{*}{ capita expenditure } & $(0.047)$ & $(0.075)$ & $(0.040)$ \\
\hline & {$[864]$} & {$[864]$} & {$[403]$} \\
\hline Monthly log sum of & 0.035 & 0.057 & 6.62 \\
\hline itemized expenditures & $(0.049)$ & $(0.079)$ & $(0.041)$ \\
\hline per capita & {$[883]$} & {$[883]$} & {$[409]$} \\
\hline
\end{tabular}

ITT column uses assignment to pavement as independent variable. TOT column instruments pavement with assignment to pavement. Regressions include a constant and the corresponding lagged dependent variable. Estimation takes survey weights into account. Standard errors clustered at the pavement-project level in parentheses. Number of observations in brackets. Significance levels reported only for ITT and TOT: * significant at $10 \% ; * *$ significant at $5 \% ; * * *$ significant at $1 \%$. 
Table 6: Effect of Street Pavement on Transportation, Labor, Health, and Schooling

\begin{tabular}{|c|c|c|c|}
\hline Transportation and Labor & ITT & TOT & Mean Control (2009) \\
\hline Cost of taxi to & -0.360 & -0.587 & 18.14 \\
\hline \multirow[t]{2}{*}{ city center } & $(0.487)$ & $(0.767)$ & $(0.697)$ \\
\hline & {$[889]$} & [889] & {$[407]$} \\
\hline \multirow[t]{3}{*}{ Time to city center (minutes) } & -0.598 & -0.989 & 19.04 \\
\hline & $(0.920)$ & $(1.52)$ & $(0.789)$ \\
\hline & [899] & [899] & {$[412]$} \\
\hline \multirow[t]{3}{*}{ Distance to nearest paved street } & $-0.46^{* * *}$ & $-0.75^{* * *}$ & 0.67 \\
\hline & $(0.10)$ & $(0.13)$ & $(0.08)$ \\
\hline & {$[898]$} & [898] & {$[411]$} \\
\hline Household head motor & $0.137^{* * *}$ & $0.212^{* * *}$ & 0.484 \\
\hline \multirow{2}{*}{ transport to work(i) } & $(0.047)$ & $(0.071)$ & $(0.043)$ \\
\hline & {$[280]$} & {$[280]$} & [109] \\
\hline \multirow[t]{3}{*}{ Weekly work hours(i) } & $2.85^{*}$ & $4.68^{*}$ & 46.92 \\
\hline & $(1.47)$ & $(2.62)$ & $(1.19)$ \\
\hline & [892] & [892] & {$[411]$} \\
\hline Plans to migrate & $-0.063^{*}$ & $-0.104^{*}$ & 0.474 \\
\hline \multirow{2}{*}{ in search of work $(=1)$} & $(0.033)$ & $(0.055)$ & $(0.027)$ \\
\hline & {$[801]$} & {$[801]$} & {$[370]$} \\
\hline Monthly log labor & 0.028 & 0.047 & 7.85 \\
\hline \multirow[t]{2}{*}{ income (1) } & $(0.058)$ & $(0.092)$ & $(0.048)$ \\
\hline & {$[765]$} & {$[765]$} & {$[367]$} \\
\hline \multicolumn{4}{|l|}{ Health } \\
\hline \multirow[t]{3}{*}{ Sick previous month $(=1)$ (i) } & -0.005 & -0.009 & 0.523 \\
\hline & $(0.025)$ & $(0.040)$ & $(0.017)$ \\
\hline & {$[3,152]$} & {$[3,152]$} & {$[1,445]$} \\
\hline Fungus, parasites skin & 0.006 & 0.010 & 0.167 \\
\hline \multirow[t]{2}{*}{ infections $(=1)$ i } & $(0.022)$ & $(0.037)$ & $(0.017)$ \\
\hline & {$[3,145]$} & {$[3,145]$} & {$[1,444]$} \\
\hline \multicolumn{4}{|l|}{ Schooling (Ages 5-17) } \\
\hline \multirow[t]{3}{*}{ School enrollment $(=1)$ (i) } & 0.018 & 0.029 & 0.841 \\
\hline & $(0.020)$ & $(0.033)$ & $(0.016)$ \\
\hline & {$[898]$} & {$[898]$} & {$[402]$} \\
\hline \multirow{3}{*}{$\begin{array}{l}\text { Absenteeism previous } \\
\text { month }(=1) \text { (i) }\end{array}$} & 0.039 & 0.064 & 0.132 \\
\hline & $(0.035)$ & $(0.056)$ & $(0.023)$ \\
\hline & {$[743]$} & {$[743]$} & {$[322]$} \\
\hline
\end{tabular}

See Table 4. 
Table 7: Heterogenous Effects by Pavement Network Intensity

\begin{tabular}{|c|c|c|c|c|}
\hline & \multirow{2}{*}{\multicolumn{2}{|c|}{$\begin{array}{l}\text { Central District } \\
\text { Pavement Projects }\end{array}$}} & \multirow{2}{*}{\multicolumn{2}{|c|}{$\begin{array}{l}\text { Non-Central District } \\
\text { Pavement Projects }\end{array}$}} \\
\hline & & & & \\
\hline & ITT & TOT & ITT & $\mathrm{TOT}$ \\
\hline \multirow[t]{3}{*}{ Log professional appraisal of property price } & 0.034 & 0.050 & $0.122^{* * *}$ & $0.216^{* * *}$ \\
\hline & $(0.044)$ & $(0.058)$ & $(0.035)$ & $(0.053)$ \\
\hline & {$[163]$} & {$[163]$} & {$[385]$} & {$[385]$} \\
\hline \multirow[t]{3}{*}{ Log professional appraisal of land price } & $0.269^{* *}$ & $0.404^{* * *}$ & $0.355^{* * *}$ & $0.634^{* * *}$ \\
\hline & $(0.111)$ & $(0.155)$ & $(0.081)$ & $(0.136)$ \\
\hline & [163] & [163] & {$[385]$} & {$[385]$} \\
\hline
\end{tabular}

Central-district pavement projects are surrounded by paved streets, whereas the other pavement projects lie on the outskirts of the city and are for the most part surrounded by unpaved streets. ITT column uses assignment to pavement as independent variable. TOT column instruments pavement with assignment to pavement. Regressions include a constant and the corresponding lagged dependent variable. Estimation takes survey weights into account. Standard errors clustered at the pavement-project level in parentheses. Number of observations in brackets. ${ }^{*}$ significant at $10 \% ; * *$ significant at $5 \% ; * * *$ significant at $1 \%$. 


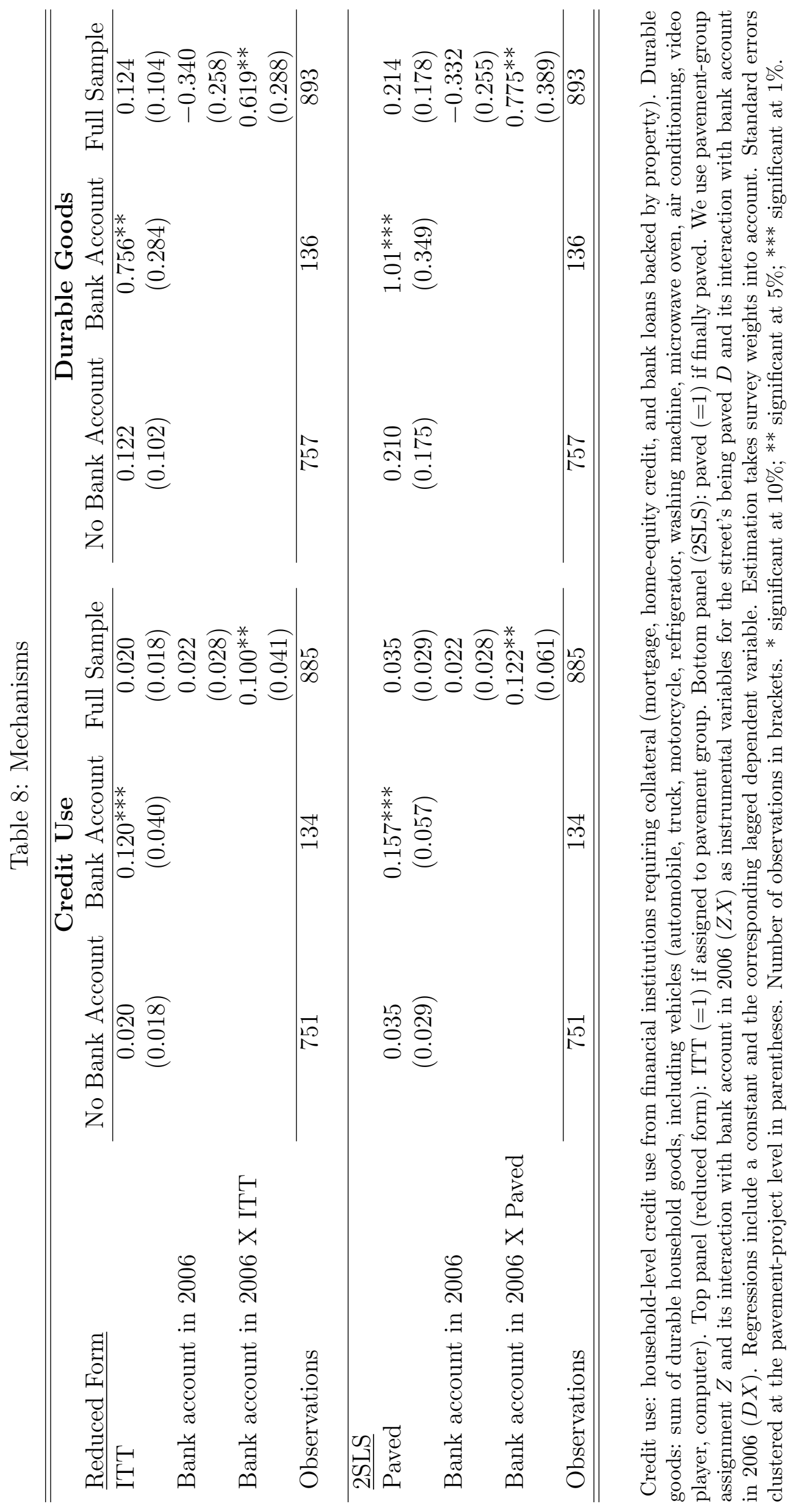


Table 9: Land-Value Increases on Paved Streets and Construction Costs

\begin{tabular}{lcccccc}
\hline \hline & Plots & $\begin{array}{c}\text { Average } \\
\text { value }\end{array}$ & $\begin{array}{c}\text { Impact } \\
\text { of Pavement }\end{array}$ & $\begin{array}{c}\text { Gains per } \\
\text { plot }\end{array}$ & $\begin{array}{c}\text { Total } \\
\text { gains }\end{array}$ & $\begin{array}{c}\text { Gain/Cost } \\
\text { ratio }\end{array}$ \\
\hline Paved & 814 & $27,844^{* * *}$ & $0.54^{* * *}$ & $15,081^{* * *}$ & $12,275,585^{* * *}$ & $1.09^{* * *}$ \\
Standard error & & $(1,508)$ & $(0.10)$ & $(3,006)$ & $(2,446,579)$ & $(0.22)$ \\
\hline \hline
\end{tabular}

Plots column reports the number of plots that were paved (residential, non-residential, and vacant). The average value of a plot is estimated by means of professional appraisals. Impact coefficient is taken from Table 3. Total costs are municipal-authority estimates of costs of the pavement program undertaken as part of this study. Figures in 2009 Mexican pesos. 2009 PPP exchange rate 8.5 pesos to the US dollar. Nominal February 2009 exchange rate 14.6 Mexican pesos to the US dollar. Standard errors clustered at the pavement-project level in parentheses. * significant at $10 \%$; $*$ significant at $5 \% ; * * *$ significant at $1 \%$. 


\section{Appendix}

Table A1: Non-Response and Recontact

\begin{tabular}{|c|c|c|c|}
\hline \multicolumn{3}{|c|}{$\begin{array}{c}2006 \\
\text { Dwellings }\end{array}$} & $\begin{array}{c}2009 \\
\text { Households }\end{array}$ \\
\hline Eligible selected & 1,275 & Follow-up & 1,231 \\
\hline Completed & 1,193 & Completed at follow up & 900 \\
\hline \multirow[t]{10}{*}{ Response rate } & $94 \%$ & Household moved & 271 \\
\hline & & Non-response & 56 \\
\hline & & Other & 4 \\
\hline & & Recontact rate & $73 \%$ \\
\hline & & $\begin{array}{l}\text { New households } \\
\text { of which: }\end{array}$ & 183 \\
\hline & & Subdivision & 22 \\
\hline & & Substitution & 120 \\
\hline & & New household & 14 \\
\hline & & New construction & 27 \\
\hline & & Completed in 2009 & 1,083 \\
\hline
\end{tabular}

Eligible-dwelling category excluded plots without a dwelling, unoccupied dwellings, and temporaryuse dwellings. The 2006 non-response is in terms of dwellings selected from the frame, and the number of dwellings with completed household survey. The 2009 recontact is in terms of households. The fact that there were 1,231 households in 1,193 dwellings in 2006 means that in some cases there was more than one household per dwelling. "Completed at follow-up" means that at least one member of the household was interviewed in 2006. "New households" means that no member of the household was interviewed in 2006. "Subdivision" means that in 2006 a household member created a new household but occupying the same plot: for example, the son having got married, continued to live in his parent's house but did not share food expenses with them. "Substitutions" means households encountered for the first time in 2009 who occupy the house inhabited by a family interviewed in 2006: for example, the house is rented. "New household" means the interviewed family is still in residence but there is now an additional household: for example, a room in the house is now rented out. "New construction" means households interviewed in 2009 whose residence was constructed since 2006. 


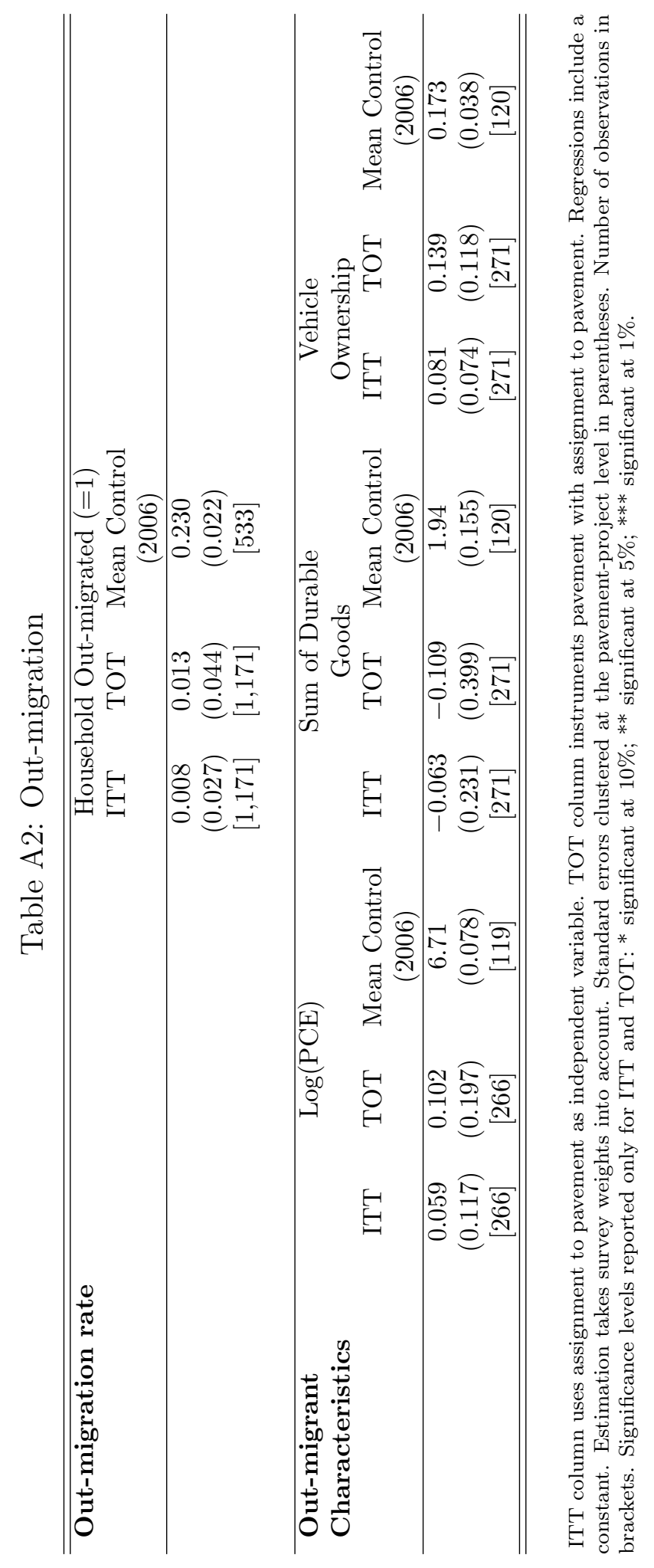




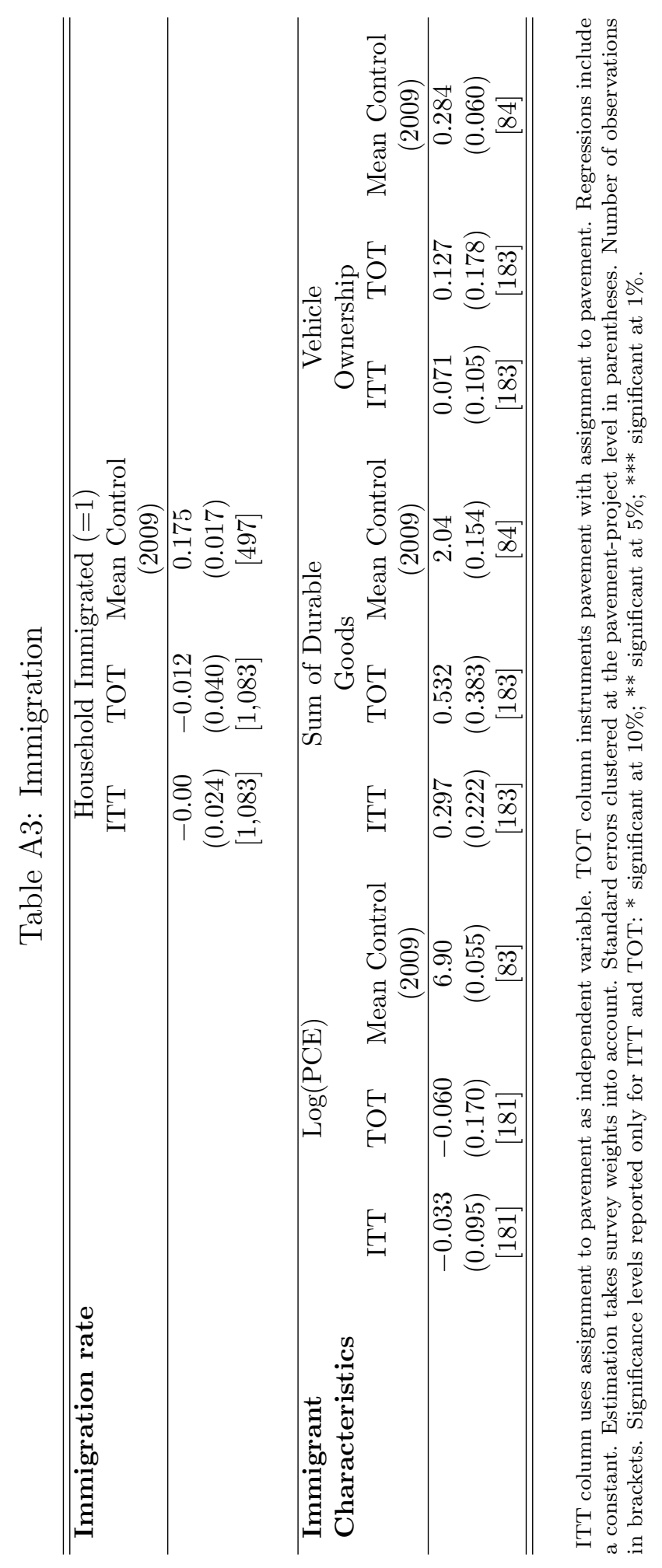


Table A4: Pre-Intervention Balance in Means (Other Outcomes)

\begin{tabular}{|c|c|c|c|c|c|c|c|}
\hline Variable & $\mathrm{ITT}=1$ & $\overline{\mathrm{ITT}}=0$ & Diff. & Variable & $\overline{\mathrm{ITT}}=1$ & $\overline{\mathrm{ITT}}=0$ & Diff. \\
\hline \multicolumn{4}{|c|}{ Demographic Indicators } & \multicolumn{4}{|c|}{ Home Characteristics (continued) } \\
\hline \multirow[t]{3}{*}{$\begin{array}{l}\text { Household members } \\
\end{array}$} & 4.08 & 4.08 & 0.00 & Gas truck delivery & 0.948 & 0.914 & 0.034 \\
\hline & $(0.09)$ & $(0.08)$ & $(0.12)$ & service $(=1)$ & $(0.020)$ & $(0.025)$ & $(0.032)$ \\
\hline & {$[487]$} & {$[413]$} & {$[900]$} & & {$[487]$} & {$[411]$} & {$[898]$} \\
\hline \multirow[t]{3}{*}{ Female $(=1)$ (i) } & 0.52 & 0.54 & -0.02 & Labor (Ages 18-65) & & & \\
\hline & $(0.008)$ & $(0.012)$ & $(0.014)$ & $\overline{\text { Works }(=1) \text { (i) }}$ & 0.66 & 0.65 & 0.01 \\
\hline & {$[1,997]$} & {$[1,716]$} & {$[3,713]$} & & $(0.016)$ & $(0.020)$ & $(0.025)$ \\
\hline \multirow[t]{3}{*}{ Adult schooling(1) } & 7.79 & 7.45 & 0.34 & & [949] & {$[829]$} & {$[1,778]$} \\
\hline & $(0.44)$ & $(0.32)$ & $(0.54)$ & Unemployed (i) & 0.043 & 0.060 & -0.017 \\
\hline & {$[916]$} & {$[815]$} & {$[1,731]$} & & $(0.011)$ & $(0.014)$ & $(0.017)$ \\
\hline \multirow[t]{3}{*}{ Adult age $(1)$} & 38.11 & 38.70 & -0.59 & & {$[567]$} & {$[499]$} & {$[1,066]$} \\
\hline & $(0.35)$ & $(0.31)$ & $(0.46)$ & Days worked (1) & 5.64 & 5.62 & 0.02 \\
\hline & [996] & {$[852]$} & {$[1,848]$} & & $(0.066)$ & $(0.084)$ & $(0.106)$ \\
\hline Home Characteristics & & & & & {$[489]$} & {$[422]$} & {$[911]$} \\
\hline \multirow[t]{3}{*}{ Homeowner $(=1)$} & 0.932 & 0.941 & -0.009 & Daily work hours (1) & 8.40 & 8.17 & 0.23 \\
\hline & $(0.017)$ & $(0.014)$ & $(0.022)$ & & $(0.173)$ & $(0.140)$ & $(0.220)$ \\
\hline & {$[486]$} & {$[411]$} & {$[897]$} & & {$[491]$} & {$[423]$} & [914] \\
\hline \multirow[t]{3}{*}{ Number of rooms } & 2.35 & 2.38 & -0.03 & Government welfare & 0.069 & 0.082 & -0.013 \\
\hline & $(0.064)$ & $(0.067)$ & $(0.091)$ & program participant & $(0.017)$ & $(0.016)$ & $(0.023)$ \\
\hline & {$[487]$} & {$[413]$} & {$[900]$} & & {$[486]$} & {$[411]$} & {$[897]$} \\
\hline Cement roof + & 2.17 & 2.21 & -0.04 & Public Safety & & & \\
\hline cement walls + & $(0.076)$ & $(0.055)$ & $(0.093)$ & Burglary in past & 0.109 & 0.113 & -0.004 \\
\hline hard floor $[0-3]$ & {$[483]$} & {$[411]$} & [894] & 12 months $(=1)$ & $(0.016)$ & $(0.015)$ & $(0.022)$ \\
\hline Bathroom inside & 0.542 & 0.577 & -0.035 & & {$[483]$} & [410] & [893] \\
\hline \multirow[t]{2}{*}{ house $(=1)$} & $(0.043)$ & $(0.036)$ & $(0.055)$ & Vehicle stolen or & 0.069 & 0.020 & 0.049 \\
\hline & {$[483]$} & {$[411]$} & {$[894]$} & vandalized (12 months) & $(0.036)$ & $(0.019)$ & $(0.040)$ \\
\hline Water connection & 0.414 & 0.467 & -0.053 & & [65] & {$[46]$} & {$[111]$} \\
\hline \multirow[t]{2}{*}{ inside house $(=1)$} & $(0.055)$ & $(0.036)$ & $(0.065)$ & Feels safe walking & 0.619 & 0.612 & 0.007 \\
\hline & {$[486]$} & {$[412]$} & {$[898]$} & in street at night & $(0.031)$ & $(0.031)$ & $(0.043)$ \\
\hline Tap water & 0.777 & 0.789 & -0.012 & $(=1)$ & {$[478]$} & {$[410]$} & {$[888]$} \\
\hline \multirow[t]{2}{*}{ connection in $\operatorname{lot}(=1)$} & $(0.050)$ & $(0.044)$ & $(0.066)$ & Business Units & & & \\
\hline & {$[486]$} & {$[412]$} & {$[898]$} & Number of employees & 1.78 & 1.56 & 0.22 \\
\hline \multirow[t]{3}{*}{ Sewerage $(=1)$} & 0.851 & 0.877 & -0.026 & & $(0.13)$ & $(0.10)$ & $(0.16)$ \\
\hline & $(0.034)$ & $(0.032)$ & $(0.047)$ & & {$[102]$} & {$[123]$} & {$[225]$} \\
\hline & {$[486]$} & {$[412]$} & {$[898]$} & Log sales & 7.72 & 7.62 & 0.10 \\
\hline \multirow[t]{3}{*}{ Electricity $(=1)$} & 0.978 & 0.971 & 0.007 & & $(0.14)$ & $(0.12)$ & $(0.19)$ \\
\hline & $(0.005)$ & $(0.017)$ & $(0.017)$ & & {$[102]$} & {$[123]$} & {$[225]$} \\
\hline & {$[485]$} & {$[412]$} & {$[897]$} & Log expenditures & 7.19 & 7.01 & 0.18 \\
\hline \multirow[t]{3}{*}{ Garbage collection $(=1)$} & 0.526 & 0.597 & -0.071 & & $(0.17)$ & $(0.15)$ & $(0.23)$ \\
\hline & $(0.055)$ & $(0.061)$ & $(0.081)$ & & [98] & {$[117]$} & {$[215]$} \\
\hline & {$[486]$} & {$[413]$} & [899] & Log profits & 6.89 & 6.89 & 0.00 \\
\hline \multirow[t]{3}{*}{ Cleanliness of street $(=1)$} & 0.37 & 0.46 & -0.09 & & $(0.13)$ & $(0.13)$ & $(0.18)$ \\
\hline & $(0.06)$ & $(0.07)$ & $(0.09)$ & & {$[94]$} & {$[107]$} & {$[201]$} \\
\hline & {$[474]$} & {$[406]$} & {$[880]$} & & & & \\
\hline
\end{tabular}

(1) denotes individual-level outcomes. Means use survey weights. Standard errors clustered at the pavement-project level in parentheses. Number of observations in brackets. Individual variables regarding labor outcomes for individuals aged 18-65. Some variable definitions: number of rooms (excluding kitchen, unless it is also used for sleeping). Government welfare programs include: Liconsa, Progresa-Oportunidades, DIF, etc. Significance levels reported only for Diff: * significant at $10 \%$;* significant at $5 \%$; ** significant at $1 \%$. 
Table A5: Possible Anticipation Effects on Housing Value

Log professional appraisal of property price

Assigned to treatment but unpaved $\quad 0.007$

$[344]$

\section{Log professional appraisal of land price}

Assigned to treatment but unpaved 0.112

$[344]$

\section{Log owner estimate of property price}

Assigned to treatment but unpaved $\quad 0.067$

\footnotetext{
"Assigned to treatment but unpaved" is a dummy for observations from street projects assigned to pavement but unpaved by the time of the second survey. Sample consists of street projects assigned to control and assigned to treatment but unpaved. Regressions include a constant and the corresponding lagged dependent variable. Estimation takes survey weights into account. Standard errors clustered at the pavement-project level in parentheses. Number of observations in brackets. ${ }^{*}$ significant at $10 \%$; ** significant at $5 \%$; *** significant at $1 \%$.
} 
Table A6: Impact of Pavement (Other Outcomes)

\begin{tabular}{|c|c|c|c|c|c|c|c|}
\hline Variable & ITT & TOT & Mean Control (2009) & Variable & ITT & TOT & Mean Control (200؟ \\
\hline \multicolumn{4}{|l|}{ Home Characteristics } & \multicolumn{4}{|c|}{ Labor (Ages 18-65, continued) } \\
\hline \multirow[t]{3}{*}{ Homeowner $(=1)$} & -0.011 & -0.019 & 0.954 & Unemployed(i) & 0.002 & 0.003 & 0.056 \\
\hline & $(0.009)$ & $(0.015)$ & $(0.014)$ & & $(0.018)$ & $(0.029)$ & $(0.014)$ \\
\hline & {$[897]$} & {$[897]$} & {$[411]$} & & {$[1,066]$} & {$[1,066]$} & {$[499]$} \\
\hline \multirow[t]{3}{*}{ Number of rooms } & -0.009 & -0.015 & 2.43 & Days worked(i) & 0.071 & 0.117 & 5.55 \\
\hline & $(0.085)$ & $(0.139)$ & $(0.079)$ & & $(0.093)$ & $(0.158)$ & $(0.080)$ \\
\hline & {$[900]$} & [900] & {$[413]$} & & [911] & {$[911]$} & {$[422]$} \\
\hline Cement roof + & -0.010 & -0.016 & 2.25 & Daily work hours (1) & $0.350^{*}$ & 0.572 & 8.20 \\
\hline cement walls + & $(0.036)$ & $(0.059)$ & $(0.047)$ & & $(0.209)$ & $(0.353)$ & $(0.167)$ \\
\hline hard floor $[0-3]$ & {$[894]$} & {$[894]$} & {$[411]$} & & {$[914]$} & {$[914]$} & {$[423]$} \\
\hline Bathroom inside & 0.009 & 0.014 & 0.561 & Government welfare & -0.003 & -0.004 & 0.033 \\
\hline \multirow[t]{2}{*}{ house $(=1)$} & $(0.037)$ & $(0.060)$ & $(0.037)$ & program participant & $(0.012)$ & $(0.019)$ & $(0.009)$ \\
\hline & {$[894]$} & [894] & {$[411]$} & & {$[897]$} & {$[897]$} & {$[411]$} \\
\hline Water connection & 0.015 & 0.024 & 0.522 & Public Safety & & & \\
\hline \multirow[t]{2}{*}{ inside house $(=1)$} & $(0.035)$ & $(0.056)$ & $(0.038)$ & $\overline{\text { Burglary in past }}$ & 0.030 & 0.050 & 0.060 \\
\hline & {$[898]$} & {$[898]$} & {$[412]$} & 12 months $(=1)$ & $(0.019)$ & $(0.033)$ & $(0.012)$ \\
\hline Tap water & 0.015 & 0.024 & 0.793 & & {$[893]$} & {$[893]$} & {$[410]$} \\
\hline \multirow[t]{2}{*}{ connection in $\operatorname{lot}(=1)$} & $(0.030)$ & $(0.047)$ & $(0.035)$ & Vehicle stolen or & 0.005 & 0.007 & 0.094 \\
\hline & {$[898]$} & {$[898]$} & {$[412]$} & vandalized (12 months) & $(0.055)$ & $(0.072)$ & $(0.044)$ \\
\hline \multirow[t]{3}{*}{ Sewerage $(=1)$} & -0.004 & -0.007 & 0.930 & & {$[111]$} & {$[111]$} & {$[46]$} \\
\hline & $(0.026)$ & $(0.042)$ & $(0.022)$ & Feels safe walking & 0.029 & 0.048 & 0.623 \\
\hline & {$[898]$} & {$[898]$} & {$[412]$} & in street at night & $(0.043)$ & $(0.067)$ & $(0.028)$ \\
\hline \multirow[t]{3}{*}{ Electricity $(=1)$} & 0.014 & 0.023 & 0.967 & $(=1)$ & {$[888]$} & {$[888]$} & {$[410]$} \\
\hline & $(0.012)$ & $(0.020)$ & $(0.019)$ & $\underline{\text { Business Units }}$ & & & \\
\hline & {$[897]$} & {$[897]$} & {$[412]$} & $\overline{\text { Number of employees }}$ & -0.03 & -0.05 & 1.67 \\
\hline \multirow[t]{3}{*}{ Garbage collection $(=1)$} & 0.015 & 0.025 & 0.707 & & $(0.14)$ & $(0.22)$ & $(0.10)$ \\
\hline & $(0.055)$ & $(0.088)$ & $(0.053)$ & & {$[248]$} & {$[248]$} & {$[125]$} \\
\hline & [899] & {$[899]$} & {$[412]$} & Log sales & -0.09 & -0.14 & 7.71 \\
\hline \multirow{3}{*}{$\begin{array}{l}\text { Gas truck delivery } \\
\text { service }(=1)\end{array}$} & -0.031 & -0.051 & 0.940 & & $(0.16)$ & $(0.25)$ & $(0.13)$ \\
\hline & $(0.024)$ & $(0.044)$ & $(0.024)$ & & {$[247]$} & {$[247]$} & {$[124]$} \\
\hline & [898] & [898] & {$[411]$} & Log expenditures & 0.09 & 0.15 & 7.19 \\
\hline \multirow[t]{3}{*}{ Cleanliness of street $(=1)$} & $0.11 * * *$ & $0.19^{* * *}$ & 0.73 & & $(0.15)$ & $(0.24)$ & $(0.13)$ \\
\hline & $(0.04)$ & $(0.06)$ & $(0.03)$ & & {$[243]$} & {$[243]$} & {$[124]$} \\
\hline & {$[880]$} & {$[880]$} & {$[406]$} & Log profits & -0.05 & -0.07 & 6.85 \\
\hline Labor (Ages 18-65) & & & & & $(0.15)$ & $(0.22)$ & $(0.11)$ \\
\hline \multirow[t]{3}{*}{ Works $(=1)$ (i) } & -0.20 & -0.034 & 0.67 & & {$[207]$} & {$[207]$} & {$[105]$} \\
\hline & $(0.020)$ & $(0.030)$ & $(0.017)$ & & & & \\
\hline & {$[1,778]$} & {$[1,778]$} & {$[829]$} & & & & \\
\hline
\end{tabular}

(1) denotes individual-level outcomes. Means use survey weights. Standard errors clustered at the pavement-project level in parentheses. Number of observations in brackets. Individual variables regarding labor outcomes for individuals aged 18-65. Some variable definitions: number of rooms (excluding kitchen, unless it is also used for sleeping). Government welfare programs include: Liconsa, Progresa-Oportunidades, DIF, etc. Significance levels reported only for ITT and TOT: * significant at $10 \%$; ** significant at $5 \%$; *** significant at $1 \%$. 
Table A7: Business-Unit Results

\begin{tabular}{|c|c|c|c|c|c|c|}
\hline \multicolumn{7}{|c|}{ Extensive Margin (Total Units) } \\
\hline & \multicolumn{2}{|c|}{ All Business Units } & \multirow[t]{2}{*}{ Difference } & \multicolumn{2}{|c|}{ All Employees } & \multirow[t]{2}{*}{ Difference } \\
\hline & 2006 & 2009 & & 2006 & 2009 & \\
\hline $\mathrm{ITT}=1$ & 102 & 123 & +21 & 182 & 202 & +20 \\
\hline $\mathrm{ITT}=0$ & 123 & 125 & +2 & 192 & 209 & +17 \\
\hline
\end{tabular}

Data from a short census of all business units in the study projects. 